\title{
Outstanding Black Physicians and Other Health Professionals in American History
}

Where there is no vision, the people perish.

—Proverbs 29:18 KJV

It is axiomatic that any attempt to create a list of the best or most important or most accomplished people in any field will be met with questions about why certain individuals were excluded or, indeed, why some were even included. No list of this type will ever satisfy everyone. However, the thought is often raised about who the outstanding physicians are and were, and it certainly is pertinent in a book on blacks in medicine. We sometimes refer to prominent physicians in terms of their demonstrated ability to overcome adversity while accomplishing enormous gains in their careers, against all odds in many cases.

What metrics should we employ to determine who should be on this select list? Often the term "great" is used to describe an individual physician's attributes. However, if greatness can be defined as extraordinary competence sustained over time, many of those who had only a relatively brief opportunity to demonstrate their expertise would not make the list, although their singular accomplishment may have been groundbreaking. So perhaps a broader criterion should be used, one that does not require a long-term application of medical prowess. I would like to suggest what that overarching criterion should be: it is the unequivocal impact that an individual physician has had in saving and rescuing the lives and health of African American and other minority, vulnerable, needy, and impoverished people, and contributing in a measurable manner to their health and well-being, either by involvement as a medical practitioner, researcher, educator, or academic standout or through leadership and activism as a champion for social justice. This is a yardstick that is long enough to qualify those who are truly deserving of such recognition but narrow enough to invoke an important amount of exclusivity. 
Who should decide and judge who is admitted to this exclusive "Hall of Fame" or pantheon of the best black physicians of all time? Several lists have been offered in the past by a variety of authors; I believe that all have had merit, but all have raised complaints of being too exclusive or unfair. In this instance, I will take the responsibility of putting forth my own list, which is based upon the tenets articulated above. I realize that it may not contain the names of all who should be so honored, but in its defense, let me explain that it is not my intention to be all-inclusive, which is impossible in any event. I simply want to make certain that the majority of those whom I have determined, based on my research, are deserving are represented here, so that the worthy deeds of so many African American physicians and their exploits do not continue to be unrecognized. This is also not a final list by any means; obviously, there can be additions as time goes by, and, judging by the outstanding accomplishments that they have made over the past 400 years in assisting in and protecting the very survival of the black race, their proud tradition will continue into the future. That is the true legacy of blacks in medicine.

\section{Past Presidents of the National Medical Association (NMA)}

(Profiles and photographs are based on available information and permissions provided by families and other sources)

1. Robert Fulton Boyd, MD, DDS (1855-1912) (Fig. 6.1) Undergraduate: Fisk University, Nashville, TN. Medical and dental school: Central Tennessee College, Nashville, TN. Physician, dentist, and professor of gynecology and clinical medicine at Meharry Medical College, Nashville, Tennessee. Founder of Mercy Hospital, Nashville, the largest hospital in the South to be owned and managed by African Americans. In his published paper, "What Are the Causes of the Great Mortality Among Negroes in the Cities of the South, and How is That Mortality to be Lessened?" he made some of the earliest and most astute observations regarding the physical condition of Afro-Americans. Along with ten others, he organized a national fraternity of black doctors, the Society of Colored Physicians and Surgeons, of which he was elected president. This group eventually became the National Medical Association [1, 2]. NMA President, 1895-1897.

2. H.T. Noel, MD. NMA President, 1898-1900.

3. O.D. Porter, MD. NMA President, 1901-1902.

4. F.A. Stewart, MD. NMA President, 1903.

5. Charles Victor Roman, MD (1864-1934) (Fig. 6.2). Medical school: Meharry Medical College. Postgraduate: Post-Graduate Medical School and Hospital of Chicago, Chicago, Illinois and the Royal Ophthalmic Hospital and Central London Ear, Nose, and Throat Hospital in London, England. Founder and first head of the Department of Ophthalmology and Otolaryngology at Meharry, serving also as professor of medical history and ethics. First editor of the Journal of the National Medical Association. Articulated the theme and 
Fig. 6.1 Robert Fulton Boyd, MD, DDS. (From a 1902 book, https://www. worldcat.org/title/ twentieth-century-negroliterature-or-a-cyclopediaof-thought-on-the-vitaltopics-relating-to-theamerican-negro-by-onehundred-of-americasgreatest-negroes/ocl c/974669349?referer=di\&h $\mathrm{t}=$ edition, via Project Gutenberg ebook version https://www.gutenberg.org/ files/18772/18772h/18772-h.htm\#Page_215, Public Domain, https:// commons.wikimedia. org/w/index. php?curid=76659470)

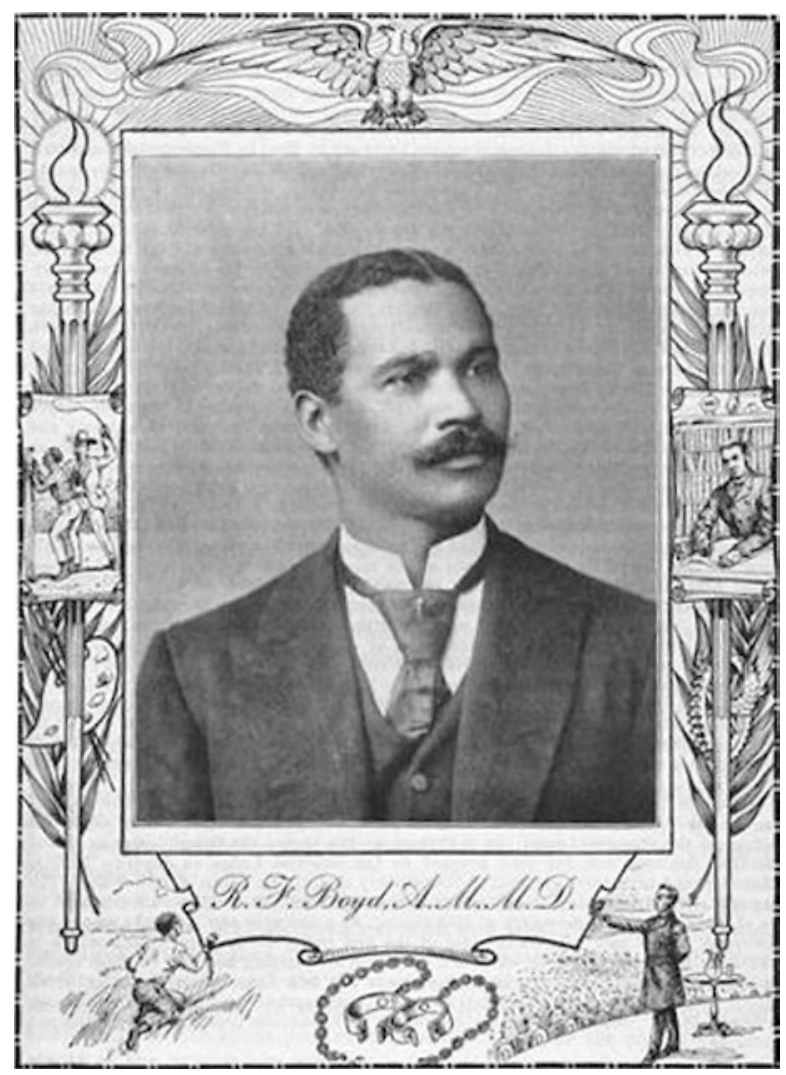

mission of the NMA in 1911, helping to stabilize the fledgling organization [2, 3]. NMA President, 1904.

6. John E. Hunter, MD. NMA President, 1905.

7. R.E. Jones, MD. NMA President, 1906.

8. Nathan Francis Mossell, MD (1856-1946) (Fig. 6.3). Undergraduate: Lincoln University, Philadelphia, PA. Medical school: University of Pennsylvania, Philadelphia. Internship: Guy's, Queen's, and St. Thomas' hospitals, London, UK. Founder, medical director, and chief of staff of the Frederick Douglass Memorial Hospital and Training School for Nurses, Philadelphia, Pennsylvania, served as its medical director for 37 years. Founder of the Philadelphia Branch of the National Association for the Advancement of Colored People (NAACP) and co-founder of the Philadelphia Academy of Medicine and Allied Sciences [4, 5]. NMA President, 1907.

9. W.H. Wright, MD. NMA President, 1908.

10. P.A. Johnson, MD. NMA President, 1909.

11. Marcus F. Wheatland, MD. NMA President, 1910.

12. Austin M. Curtis, MD. NMA President, 1911.

13. H.F. Gamble, MD. NMA President, 1912. 
Fig. 6.2 Charles Victor Roman, MD. (๔ Special Collections and Archives, Tennessee State University, with permission)

Fig. 6.3 Nathan Francis Mossell, MD (Unknown The Crisis (Jan 1912), p. 120, Public Domain, https://commons. wikimedia.org/w/index. php?curid=69394930)
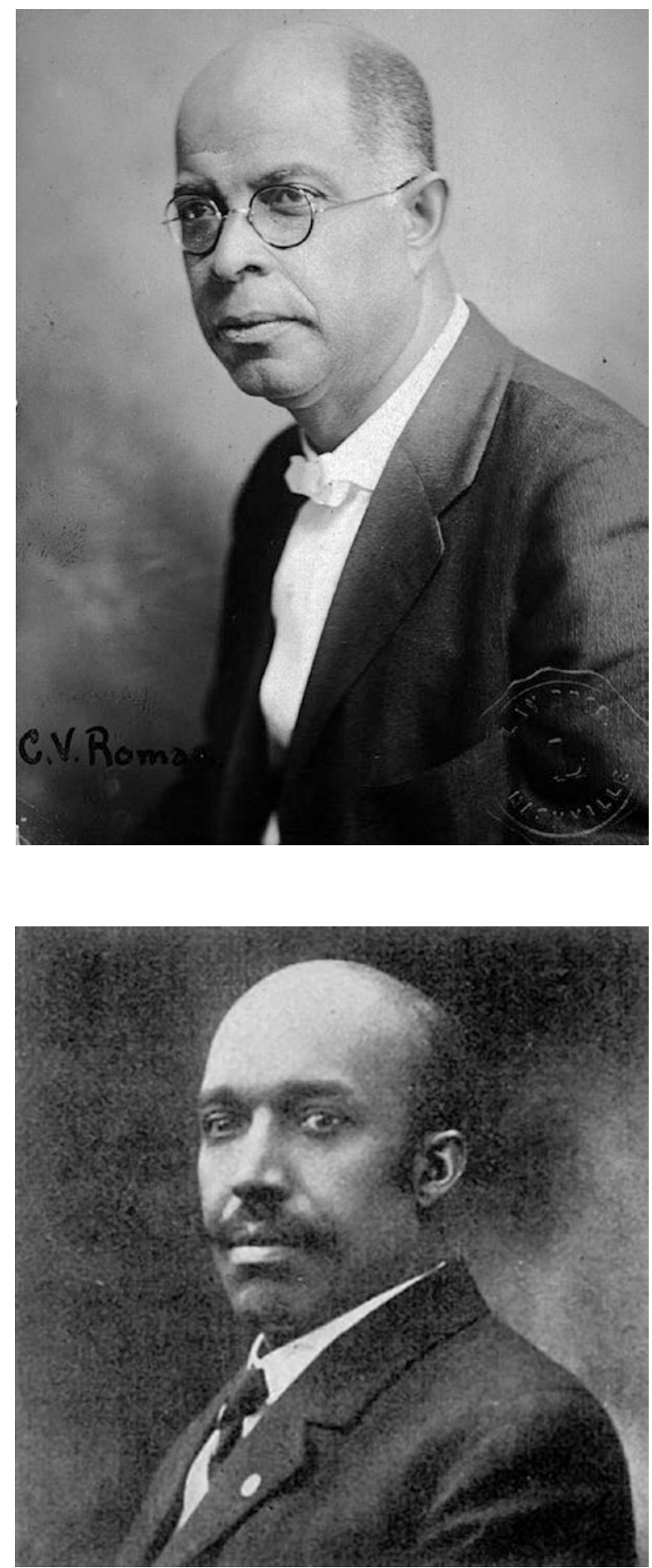
14. John A. Kenny, Sr., MD. NMA President, 1913.

15. A.M. Brown, MD. NMA President, 1914.

16. F.S. Hargraves, MD. NMA President, 1915.

17. Ulysses Grant Dailey, MD. NMA President, 1916.

18. D.W. Byrd, MD. NMA President, 1917.

19. George W. Cabaniss, MD. NMA President, 1918.

20. D.A. Ferguson, DDS. NMA President, 1919.

21. J.W. Jones, MD, NMA President, 1920.

22. John P. Turner, MD. NMA President, 1921.

23. H.M. Green, MD. NMA President, 1922.

24. J. Edward Perry, MD. NMA President, 1923.

25. John O. Plummer, MD. NMA President, 1924.

26. Michael Q. Dumas, MD. NMA President, 1925.

27. Walter G. Alexander, MD. NMA President, 1926.

28. Carl G. Roberts, MD. NMA President, 1927.

29. C.V. Freeman, DDS. NMA President, 1928.

30. T. Spotuas Burwell, MD. NMA President, 1929.

31. L.A. West, MD, NMA President, 1930.

32. W.H. Higgins, MD. NMA President, 1931.

33. Peter M. Murray, MD. NMA President, 1932.

34. C. Hamilton Francis, MD. NMA President, 1933.

35. Midian O. Bousfield, MD. NMA President, 1934.

36. John H. Hale, MD. NMA President, 1935.

37. W. Harry Barnes, MD. NMA President, 1936.

38. Roscoe C. Giles, MD. NMA President, 1937.

39. Lyndon M. Hill, MD. NMA President, 1938.

40. George W. Bowles, MD. NMA President, 1939.

41. Albert W. Dumas, Sr., MD. NMA President, 1940.

42. Kenneth W. Clement, MD. NMA President, 1941.

43. Arthur M. Vaughn, MD. NMA President, 1942.

44. Henry Eugene Lee, MD. NMA President, 1943.

45. T. Manuel Smith, MD. NMA President, 1944-1945.

46. Emory I. Robinson, MD. NMA President, 1946.

47. Walter M. Young, MD. NMA President, 1947.

48. J.A.C. Lattimore, MD. NMA President, 1948.

49. C. Austin Whittier, MD. NMA President, 1949.

50. C. Herbert Marshall, MD. NMA President, 1950.

51. Henry H. Walker, MD. NMA President, 1951.

52. Joseph G. Gathings, MD. NMA President, 1952.

53. Witter C. Atkinson, MD. NMA President, 1953.

54. Porter Davis, MD. NMA President, 1954.

55. Matthew Walker, MD. NMA President, 1955.

56. A.C. Terrence, MD. NMA President, 1956.

57. T.R.M. Howard, MD. NMA President, 1957.

58. Arthur M. Townsend, Jr., MD. NMA President, 1958. 
59. R. Stillman Smith, MD. NMA President, 1959.

60. Edward C. Mazique, MD (1911-1987). Undergraduate: Morehouse College, Atlanta, GA. Medical school: Howard University College of Medicine, Washington, DC. Postgraduate: Internship and residency, Freedmen's Hospital, Internal Medicine. Master of Education (MEd), Atlanta University. Past President, Medico-Chirurgical Society of the District of Columbia. Former member and medical staff, Georgetown University Hospital and Providence Hospital. Chaired the Health Services Coordination Committee for the Poor People's Campaign March on Washington in 1968. NMA President, 1960.

61. James T. Aldrich, MD. NMA President, 1961.

62. Vaughn C. Mason, MD. NMA President, 1962.

63. John A. Kenney, Jr., MD. NMA President, 1963.

64. W. Montague Cobb, MD, PhD (1904-1990) (Fig. 6.4). Undergraduate: Amherst College, Amherst, MA. Medical school: Howard University College of Medicine. Postgraduate: $\mathrm{PhD}$ in Anatomy and Anthropology, Western Reserve University, Cleveland, OH. Chair, Department of Anatomy (1947-1969), and the first to be named a distinguished professor at Howard University. Principal historian of the African American in medicine and editor of the Journal of the National Medical Association (1950-1977). Engaged in the struggle for civil rights and for improved medical care for African Americans, as well as racial integration of hospitals. Lobbied for the passage of Medicare-Medicaid legislation. President, NAACP 1976-1982 [6]. NMA President, 1964.

Fig.6.4 W. Montague Cobb, MD, PhD. (Courtesy National Library of Medicine Digital Collection. NLM Unique ID: 101412157; with kind permission from the Cobb family)

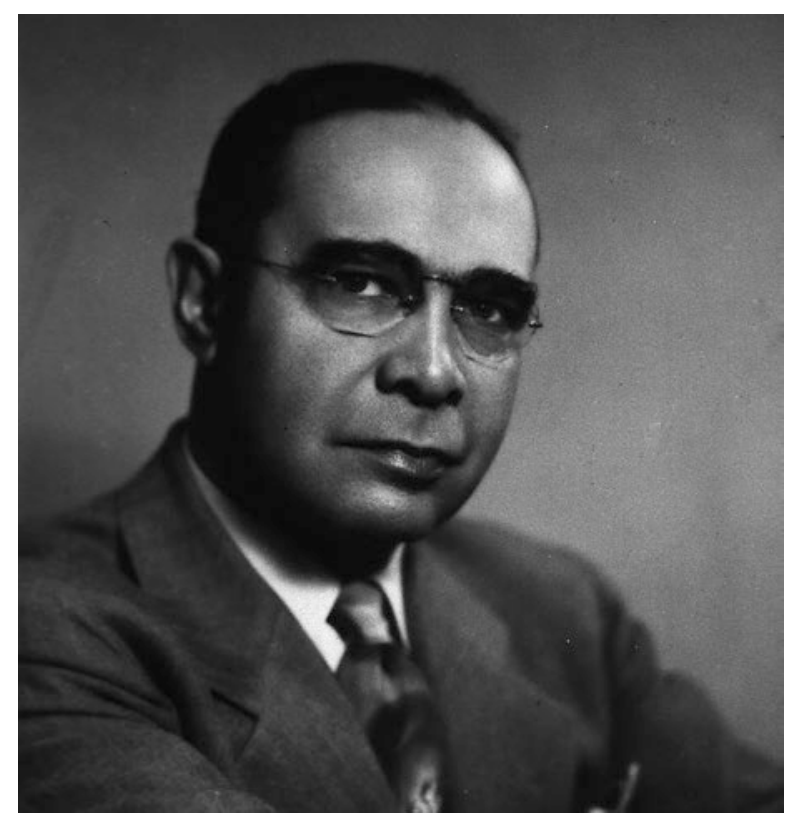


65. Leonidas H. Berry, MD. NMA President, 1965.

66. John L.S. Holloman, Jr., MD. NMA President, 1966.

67. Lionel F. Swann, MD. NMA President, 1967.

68. James M. Whittico, Jr., MD. NMA President, 1968.

69. Julius W. Hill, MD. NMA President, 1969.

70. W.T. Armstrong, MD. NMA President, 1970.

71. Emerson C. Walden, Sr., MD. NMA President, 1971.

72. Edmund C. Casey, MD. NMA President, 1972.

73. Emery L. Rann, MD. NMA President, 1973.

74. Vernal G. Cave, MD. NMA President, 1974.

75. Jasper F. Williams, MD. NMA President, 1975.

76. Arthur H. Coleman, MD. NMA President, 1976.

77. Charles C. Bookert, MD. NMA President, 1977.

78. Jesse B. Barber, Jr., MD. NMA President, 1978.

79. Robert E. Dawson, MD. NMA President, 1979.

80. Vertis R. Thompson, MD. NMA President, 1980.

81. Frank S. Royal, Sr., MD (Fig. 6.5). Undergraduate: Virginia Union University, Richmond, VA. Medical school: Meharry Medical College. Specialty: Family

Fig. 6.5 Frank S. Royal, Sr., MD. (Photograph courtesy of Dr. Royal)

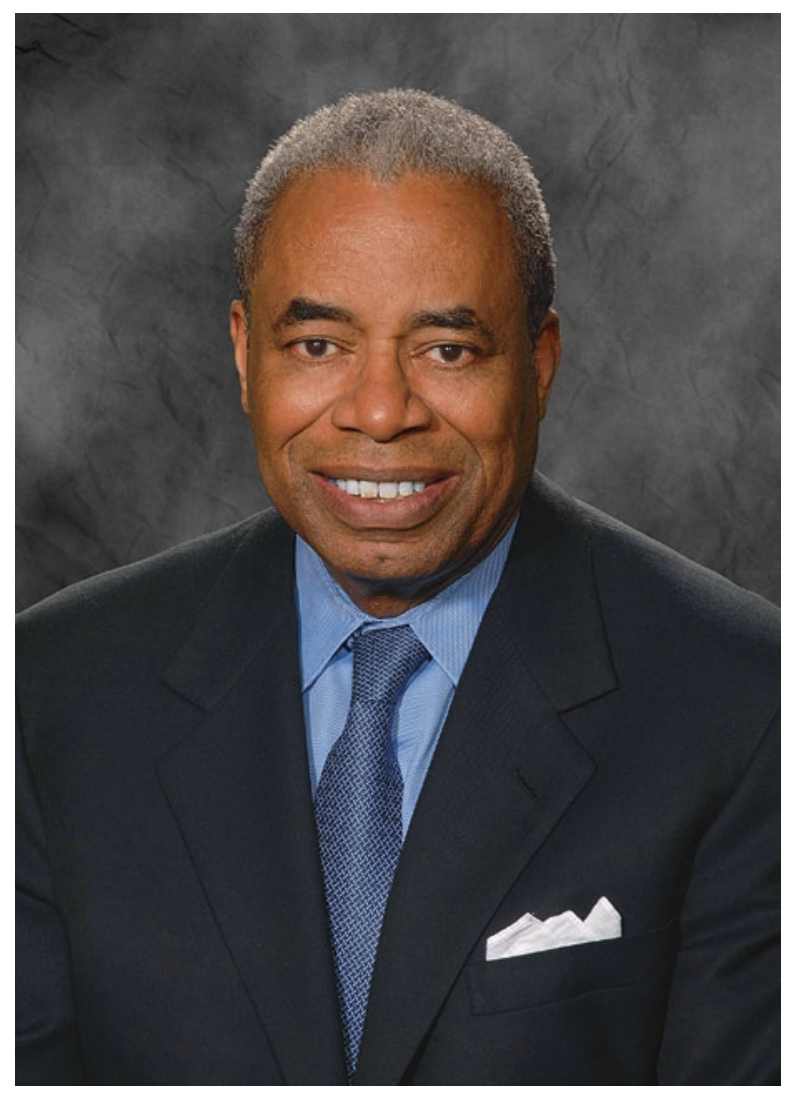


medicine. Assistant Clinical Professor of Family Medicine, Medical College of Virginia, Richmond, VA. Private practice, Bon Secours Health System. NMA President, 1981.

82. Robert L. M. Hilliard, MD. NMA President, 1982.

83. Lucius C. Earles, III, MD. NMA President, 1983.

84. Phillip M. Smith, MD. NMA President, 1984.

85. Edith Irby Jones, MD (1927-2019) (Fig. 6.6). Undergraduate: Knoxville College, Knoxville, TN. Medical school: University of Arkansas School of Medicine, Little Rock (first black student). Specialty: Internal medicine/cardiology. Only female founding member, Association of Black Cardiologists (ABC). Two international healthcare centers bear her name: Dr. Edith Irby Jones Clinic in Vaudreuil, Haiti, which she helped found in 1991, and the Dr. Edith Irby Jones Emergency Clinic in Veracruz, Mexico. NMA President, 1985 (first female President).

86. John O. Brown, MD. NMA President, 1986.

87. John M. Joyner, MD. NMA President, 1987.

88. Frank E. Staggers, Sr., MD. NMA President, 1988.

89. Vivian W. Pinn, MD (Fig. 6.7). Undergraduate: Wellesley College, Wellesley, MA. Medical school: University of Virginia, Charlottesville, VA (the only woman/minority in her class). Postgraduate training: Harvard Medical School,

Fig.6.6 Edith Irby Jones, MD. (Photograph courtesy of the National Medical Association)

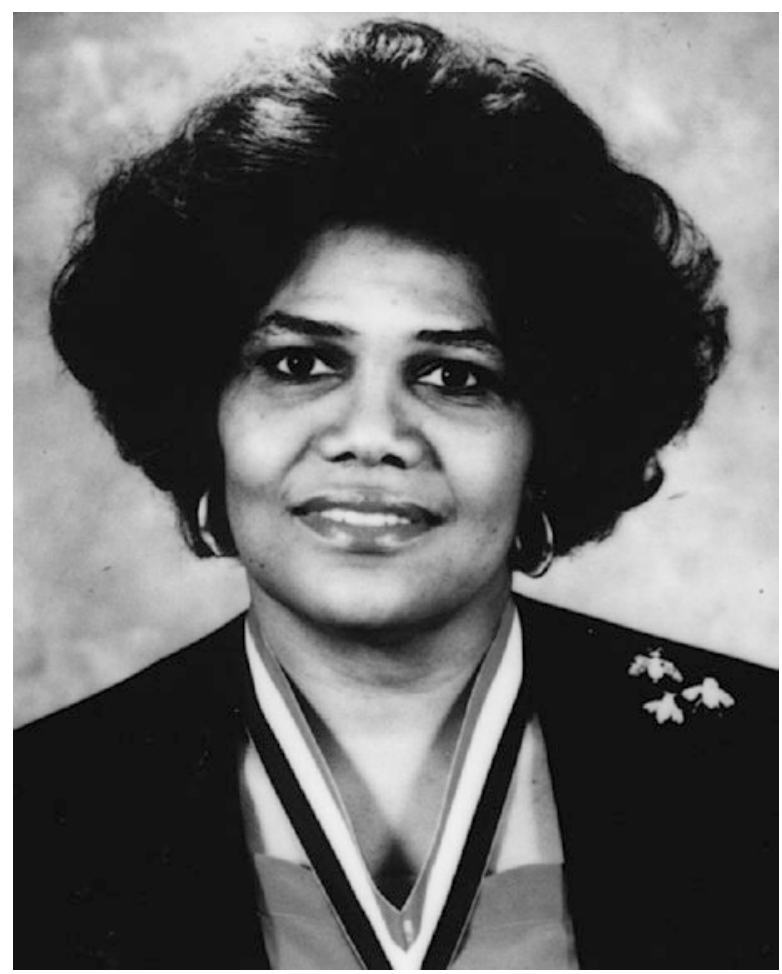


Fig. 6.7 Vivian W. Pinn, MD. (Photograph courtesy of Dr. Pinn)

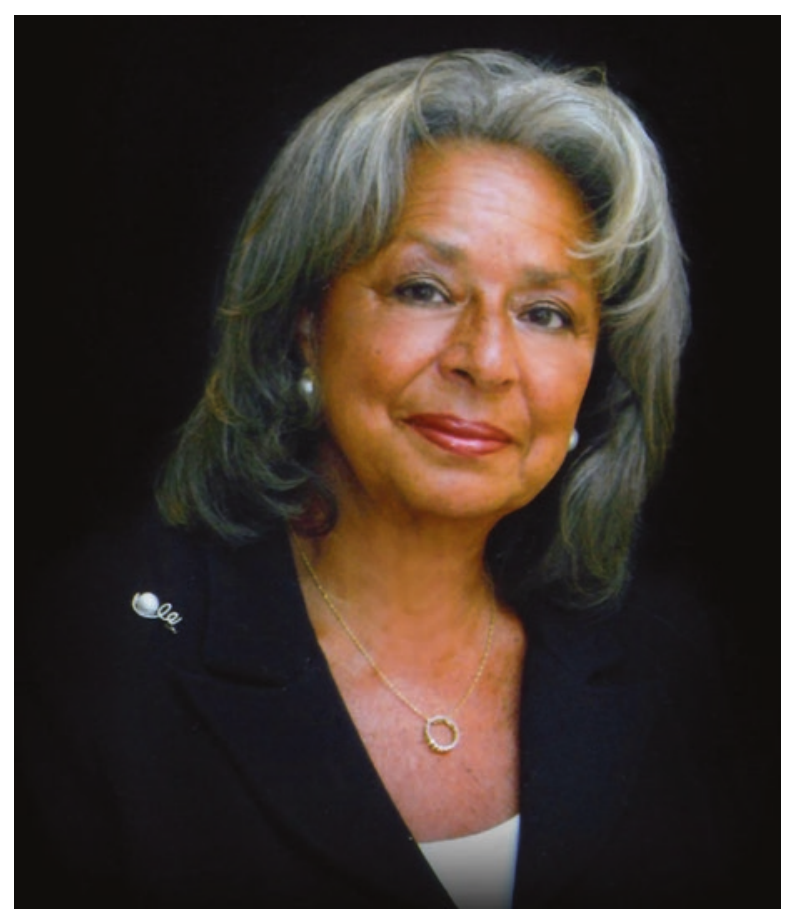

Boston, MA. Specialty: Pathology. Associate Professor of Pathology and Assistant Dean of Student Affairs at Tufts; Professor and Chair Department of Pathology, Howard University College of Medicine. Founding Director, Office of Research on Women's Health, National Institutes of Health (NIH); Senior Scientist Emerita, Fogarty International Center, NIH. Fellow of the American Academy of Arts and Sciences and the National Academy of Medicine. Chair of the NMA Past Presidents' Council (PPC). NMA President, 1989.

90. Charles Johnson, MD (Fig. 6.8). Undergraduate: Howard University. Medical school: Howard University College of Medicine. Specialty: Endocrinology. Professor of Medicine Emeritus, Duke University. Served in the US Air Force as a fighter pilot. NMA President, 1990.

91. Alma Rose George, MD. NMA President, 1991.

92. Richard O. Butcher, MD. NMA President, 1992.

93. Leonard E. Lawrence, MD (Fig. 6.9). Undergraduate: Indiana University. Medical school: Indiana University School of Medicine, Indianapolis. Specialty: Psychiatry/child psychiatry. Emeritus Professor, University of Texas-UT Health San Antonio. NMA President, 1993.

94. Tracy Matthew Walton, Jr., MD (1931-2018) (Fig. 6.10). Undergraduate: Morgan State College, Baltimore, MD. Medical school: Howard University College of Medicine. Specialty: Radiology. Served in over 25 academic and professional capacities and community programs. Held every office in the NMA. NMA President, 1994. 
Fig. 6.8 Charles Johnson, MD. (Photograph courtesy of the National Medical Association)

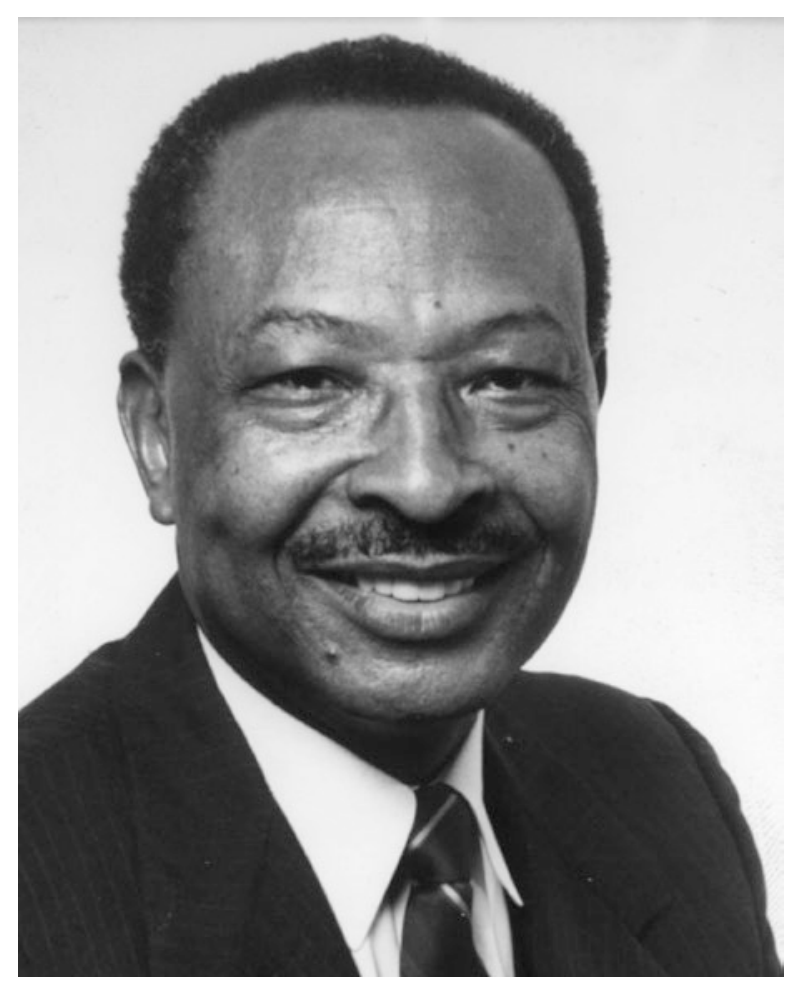

95. Yvonnecris Smith Veal, MD (Fig. 6.11). Undergraduate: Hampton Institute, Hampton, VA. Medical school: Medical College of Virginia. Specialties: Occupational medicine and pediatrics. Former Senior Medical Director, Eastern Region, US Postal Service; former Attending Physician, Pediatrics and Cardiology, Downstate Medical Center. NMA President, 1995.

96. Randall C. Morgan, MD, MBA (Fig. 6.12). Undergraduate: Grinnell College, Grinnell, IA. Medical school: Howard University College of Medicine. Postgraduate: Master of Business Administration (MBA), University of South Florida, Tampa. Specialty: Orthopedic surgery. Executive Director, W. Montague Cobb/NMA Health Institute. Clinical Assistant Professor of Orthopedic Surgery, Florida State University, Tallahassee. Clinical Associate Professor of Orthopedic Surgery, Emeritus, Indiana University School of Medicine. NMA President, 1996.

97. Nathaniel H. Murdock, MD. NMA President, 1997.

98. Gary C. Dennis, MD (Fig. 6.13). Undergraduate: Boston University, Boston, MA. Medical school: Howard University College of Medicine. Postgraduate: Training in Neurosurgery, Baylor College of Medicine, Houston, TX. Past Associate Professor and Former Chief, Division of Neurosurgery, Howard University. Past President, Medical Society of the District of Columbia. NMA President, 1998. 
Fig. 6.9 Leonard

E. Lawrence,

MD. (Photograph courtesy

of Dr. Lawrence)

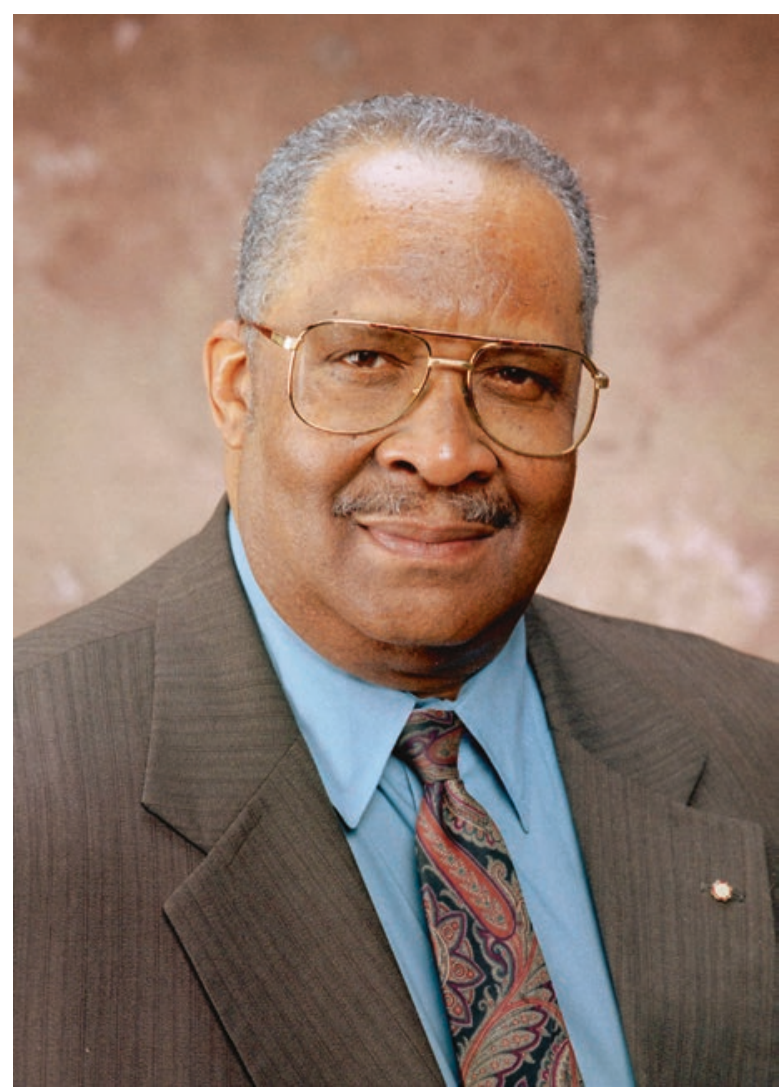

99. Walter W. Shervington, MD. NMA President, 1999. Died in 2000 while serving his term.

100. Javette C. Orgain, MD, MPH (Fig. 6.14). Undergraduate: University of Illinois Chicago. Medical school: University of Illinois at Chicago. Postgraduate: Master of Public Health (MPH), University of Illinois School of Public Health. Specialty: Family medicine. Associate Professor, Department of Family Medicine, University of Illinois at Chicago. Former Assistant Dean of the Urban Health Program, University of Illinois at Chicago College of Medicine. NMA President, 1999 (completed Dr. Shervington's term).

101. Rodney G. Hood, MD, (Fig. 6.15) Undergraduate: Northeastern University School of Pharmacy, Boston, MA. Medical school: University of California (UC) San Diego School of Medicine. Specialty: Internal medicine. Founder and President, Multicultural Healthcare Foundation. CEO, Careview Medical Group. Assistant Clinical Professor of Medicine, UCSD. Editorial Board, Journal of Racial and Ethnic Health Disparities. Commissioner and Chair, San Diego Gang Commission for Prevention and Intervention. NMA President, 2000. 
Fig. 6.10 Tracy Matthew Walton, Jr.,

MD. (Photograph courtesy of the National Medical Association)

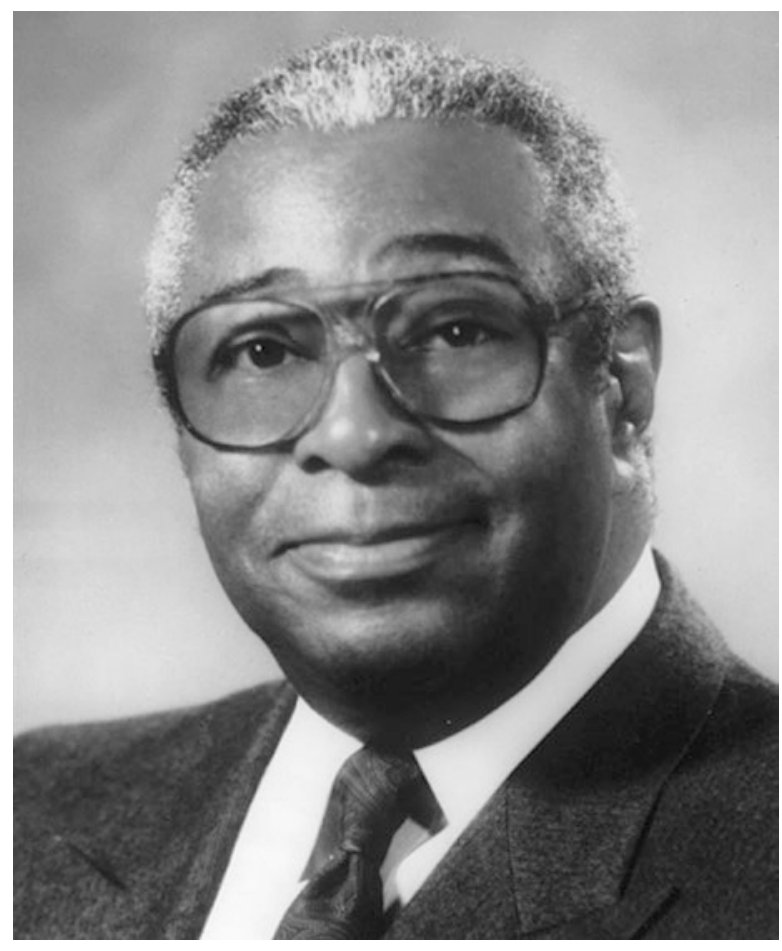

Fig. 6.11 Yvonnecris Smith Veal MD. (Photograph courtesy of the National Medical Association)

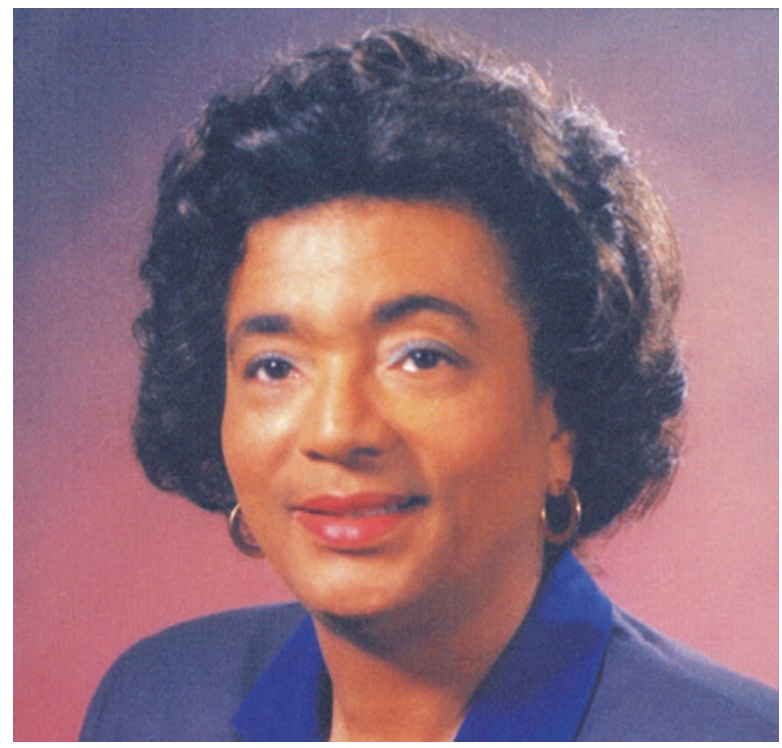


Fig.6.12 Randall C. Morgan, Jr., MD, MBA. (Photograph courtesy of Dr. Morgan)

Fig. 6.13 Gary C. Dennis, MD. (Photograph courtesy of Dr. Dennis)

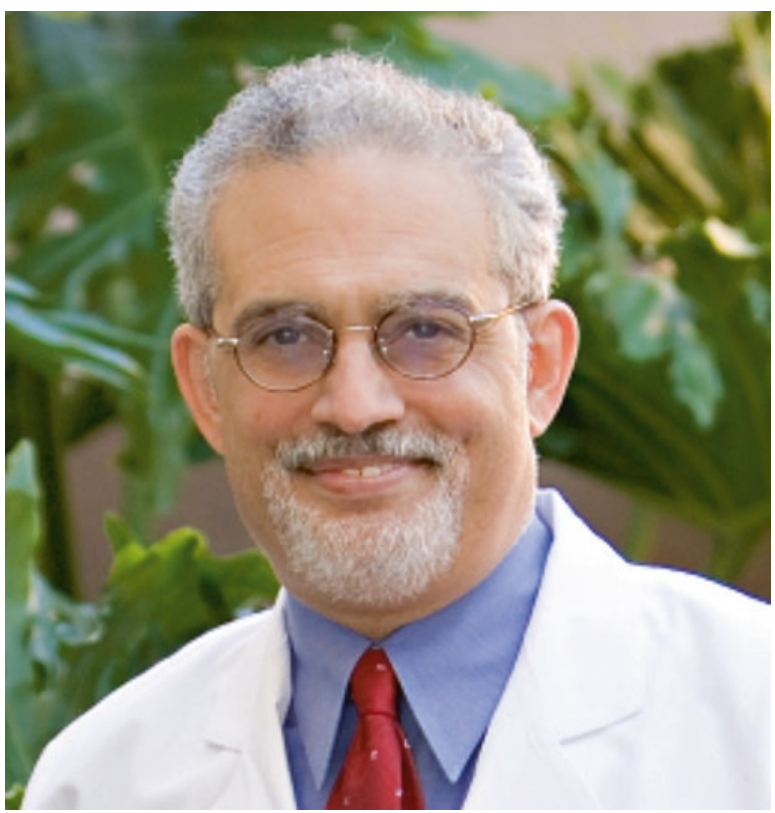


Fig. 6.14 Javette C. Orgain, MD, MPH. (Photograph courtesy of Dr. Orgain)

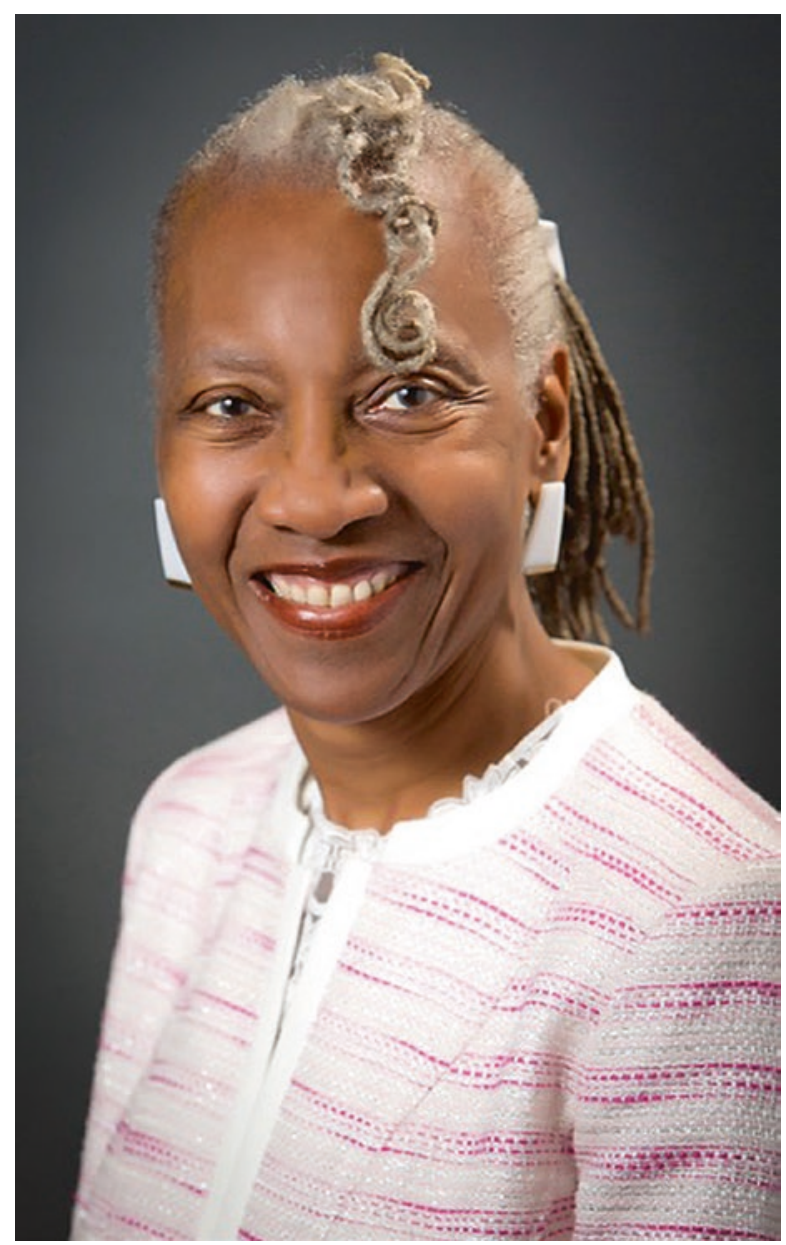

102. Lucille C. Norville Perez, MD (Fig. 6.16). Undergraduate: Manhattanville College. Medical school: New York Medical College, Purchase, NY. Specialty: Pediatrics and adolescent medicine. Formerly, National Health Director, NAACP; Associate Director of the Center for Substance Abuse Prevention at the Substance Abuse and Mental Health Services Administration at the US Department of Health and Human Services; Assistant Professor of Clinical Pediatrics, Mt. Sinai Medical Center, New York City. NMA President, 2001.

103. Laverne Natalie Carroll, MD (Fig. 6.17). Undergraduate: Lake Forest College, Lake Forest, IL. Medical school: Meharry Medical College. Specialty: Obstetrics/gynecology. Former Chair, Department of Obstetrics/Gynecology, St. Elizabeth's Hospital, Houston. Associate Clinical Professor of Obstetrics/ Gynecology, McGovern Medical School, UT Health Science Center, Houston. NMA President, 2002. 
Fig. 6.15 Rodney G. Hood, MD. (Photograph courtesy of the National Medical Association)

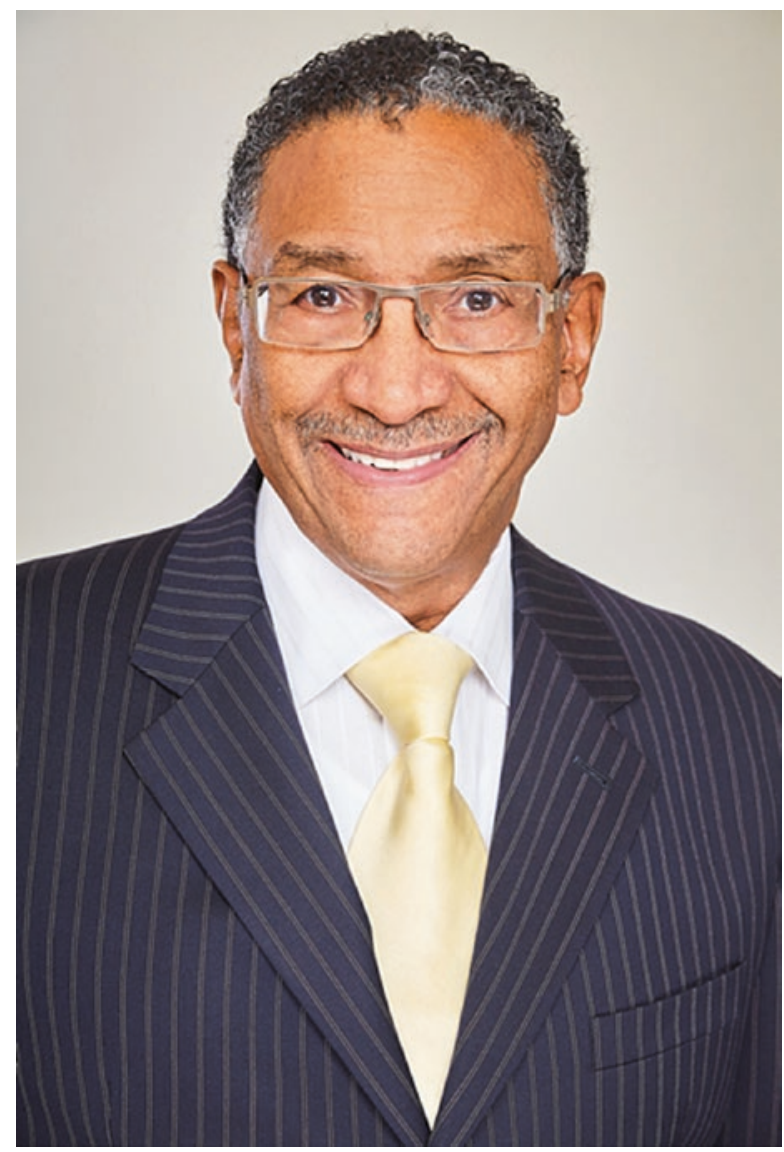

104. Randall W. Maxey, MD, PhD (Fig. 6.18) Undergraduate: University of Cincinnati, Ohio. Medical school: Howard University College of Medicine. Postgraduate: Residency, Harlem Hospital, Internal Medicine; Fellowship, State University of NY (SUNY) Downstate Medical Center, Nephrology; $\mathrm{PhD}$, Cardiovascular Pharmacology, Howard University College of Medicine. Specialty: Internal medicine/nephrology. Formerly, Assistant Professor of Medicine, SUNY Downstate. Alumnus of the Year, Howard University College of Medicine, 2002. CEO, Biometrics Management Services. Founder, Chairman, and CEO, American Dialysis Holdings. NMA President, 2003.

105. Winston Price, MD (Fig. 6.19). Undergraduate: Brooklyn College of CUNY. Medical school: Cornell University Medical College (Weill Cornell Medicine, New York). Specialty: Pediatrics. Chief of Staff, Memorial Hospital and Manor, Bainbridge, GA. President and Chair, National African American Drug Policy Coalition. Clinical Dean, American University of Antigua. NMA President, 2004. 
Fig. 6.16 Lucille

C. Norville Perez,

MD. (Photograph courtesy

of the National Institutes

of Health)

Fig. 6.17 LaVerne Natalie Carroll, MD. (Photograph courtesy of the National Medical Association)
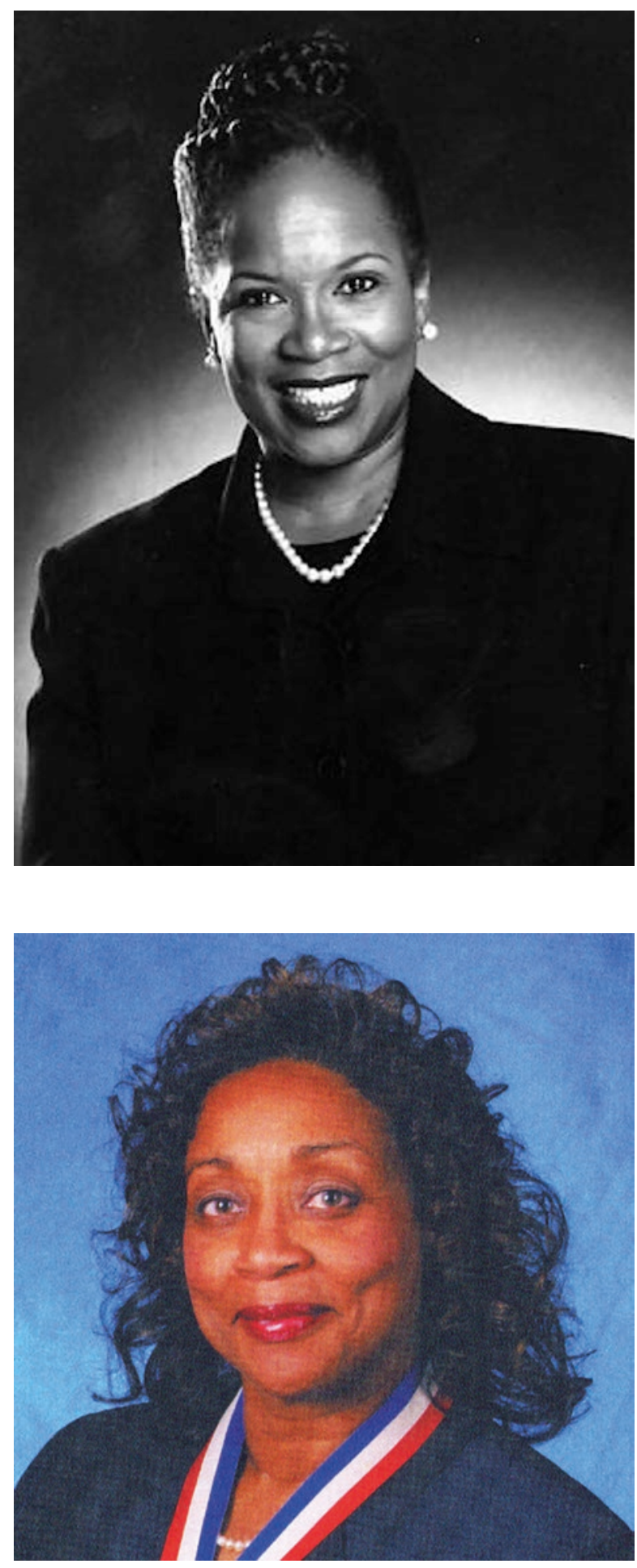
Fig. 6.18 Randall

W. Maxey, MD,

$\mathrm{PhD}$. (Photograph courtesy of the National Medical Association)

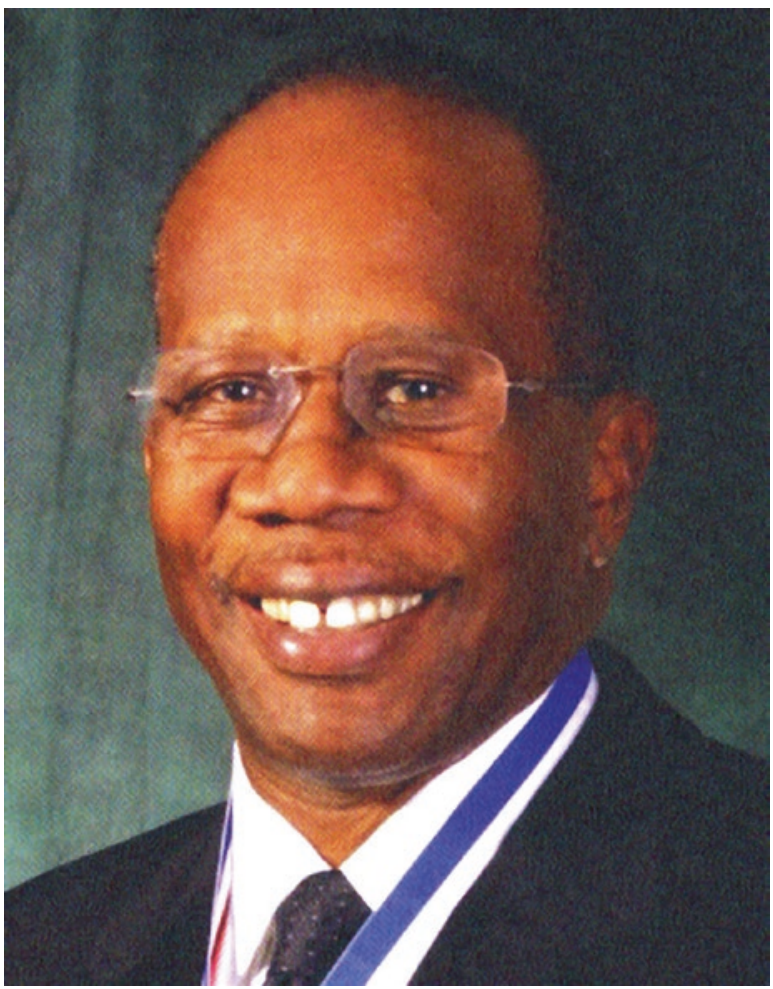

Fig. 6.19 Winston Price, MD. (Photograph courtesy of Dr. Price)

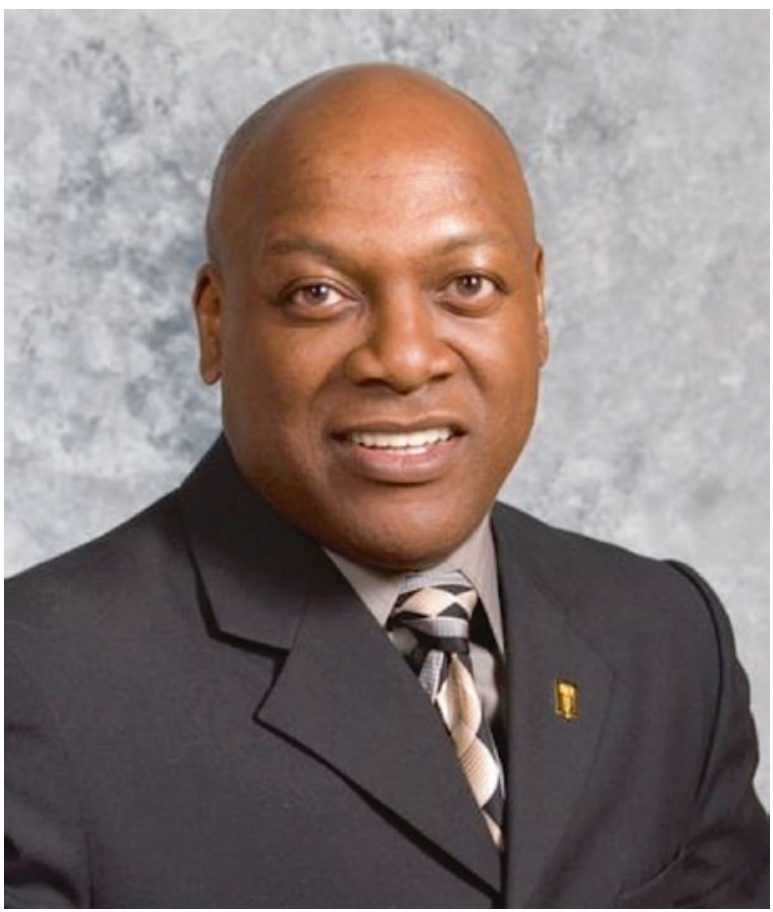


106. Sandra L. Gadson, MD (Fig. 6.20). Undergraduate: Hampton University, Hampton, VA. Medical school: Meharry Medical College. Specialty: Internal medicine/nephrology. Assistant Professor, Internal Medicine, Indiana University. Nephrology Associates of Northern Indiana. NMA President, 2005.

107. Albert W. Morris Jr., MD (Fig. 6.21). Undergraduate: Howard University. Medical school: Howard University College of Medicine. Specialty: Radiology. Diagnostic radiologist (retired), US Department of Veterans Affairs (VA) Health Care System, Georgia. NMA President, 2006.

108. Nelson L. Adams, III, MD (Fig. 6.22). Undergraduate: Howard University. Medical school: Meharry Medical College. Additional: Master of Arts, New Orleans Baptist Theological Seminary. Specialty: Obstetrics/gynecology. Chief of Staff and Chair, Department of Obstetrics/Gynecology, Jackson North Medical Center, Miami, FL. Chair, Sunshine State Health Plan. NMA President, 2007.

109. Carolyn Barley Britton, MD, MS, (Fig. 6.23). Undergraduate: Oberlin College, Oberlin, OH. Medical school: New York University. Specialty: Neurology. Associate Attending Physician, Columbia University Vagelos College of Physicians and Surgeons and New York Presbyterian Milstein Hospital. Associate Professor of Neurology, Columbia University Vagelos College of

Fig. 6.20 Sandra

L. Gadson,

MD. (Photograph courtesy of the National Medical Association)

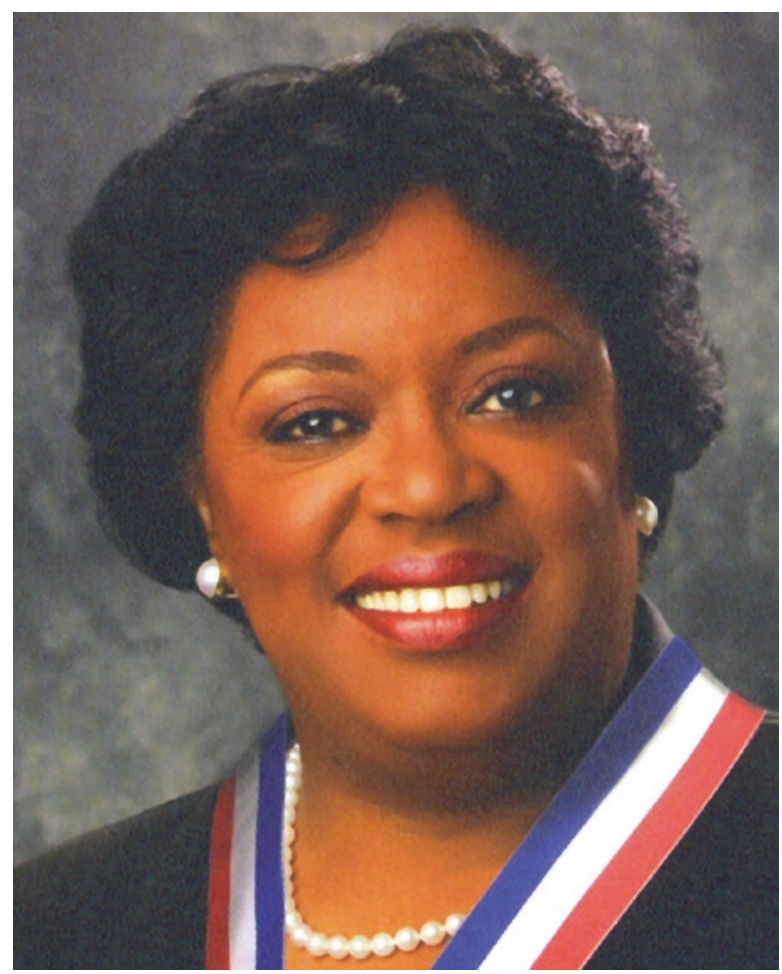


Fig. 6.21 Albert

W. Morris Jr.,

MD. (Photograph courtesy

of Dr. Morris)

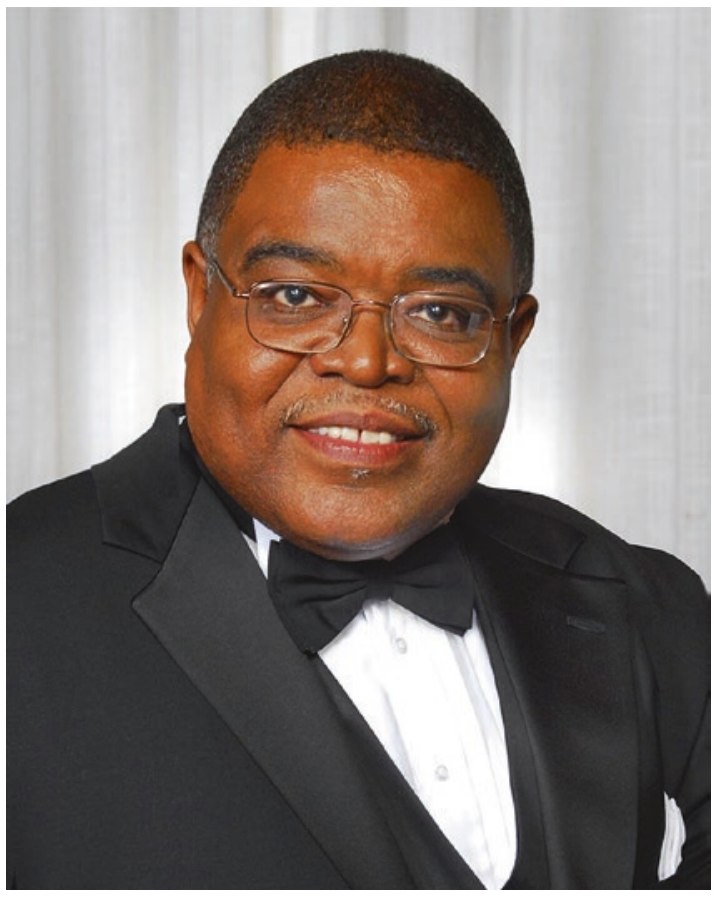

Fig. 6.22 Nelson

L. Adams, III,

MD. (Photograph courtesy

of Dr. Adams)

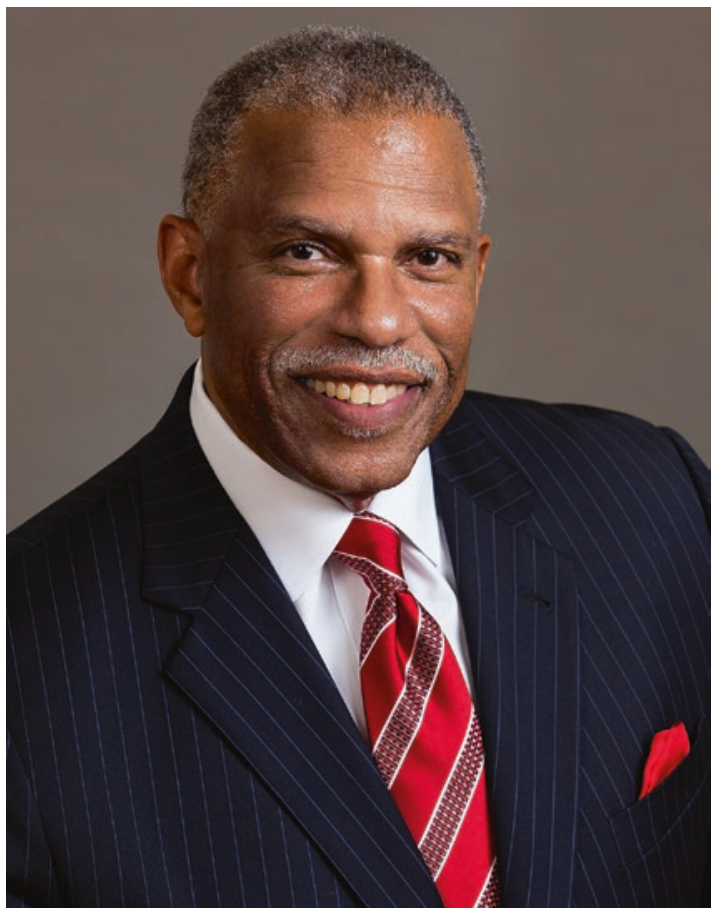


Fig. 6.23 Carolyn Barley Britton, MD,

MS. (Photograph courtesy of the National Medical Association)

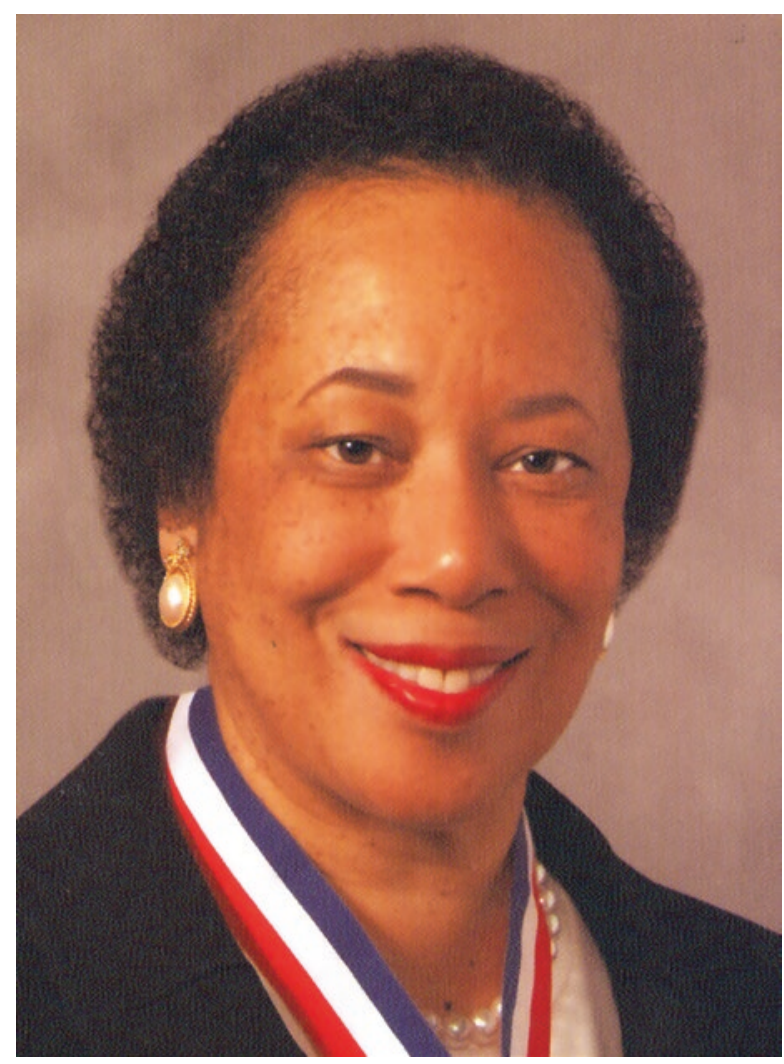

Physicians and Surgeons. Former Director of Ambulatory Care, Department of Neurology, Columbia University Medical Center. NMA President, 2008.

110. Willarda V. Edwards, MD, MBA (Fig. 6.24). Undergraduate: University of Texas at El Paso. Medical school: University of Maryland School of Medicine, Baltimore. Specialty: Internal medicine. Assistant Professor, University of Maryland Medical Center. Commander, US Navy. Member Board of Trustees, AMA. Private practice, Baltimore, MD. NMA President, 2009.

111. Leonard Weather, Jr., MD, RPh (Fig. 6.25). Undergraduate: Howard University School of Pharmacy. Medical school: Rush Medical College, Chicago, IL. Postgraduate: Training in Obstetrics/Gynecology, Johns Hopkins University Hospital, Baltimore, MD. Director, Omni Fertility and Laser Institute. Grand President, Chi Delta $\mathrm{Mu}$ Medical Fraternity. NMA President, 2010.

112. Cedric M. Bright, MD (Fig. 6.26). Undergraduate: Brown University, Providence, RI. Medical school: University of North Carolina School of Medicine, Chapel Hill. Specialty: Internal medicine. Associate Dean for Admissions, Professor of Internal Medicine, and Interim Associate Dean of Diversity and Inclusion, Brody School of Medicine, Greeneville NC. NMA President, 2011. 
Fig. 6.24 Willarda

V. Edwards, MD,

MBA. (Photograph

courtesy of Dr. Edwards)

Fig. 6.25 Leonard

Weather, Jr., MD, RPh.

(Photograph courtesy of Dr. Weather)
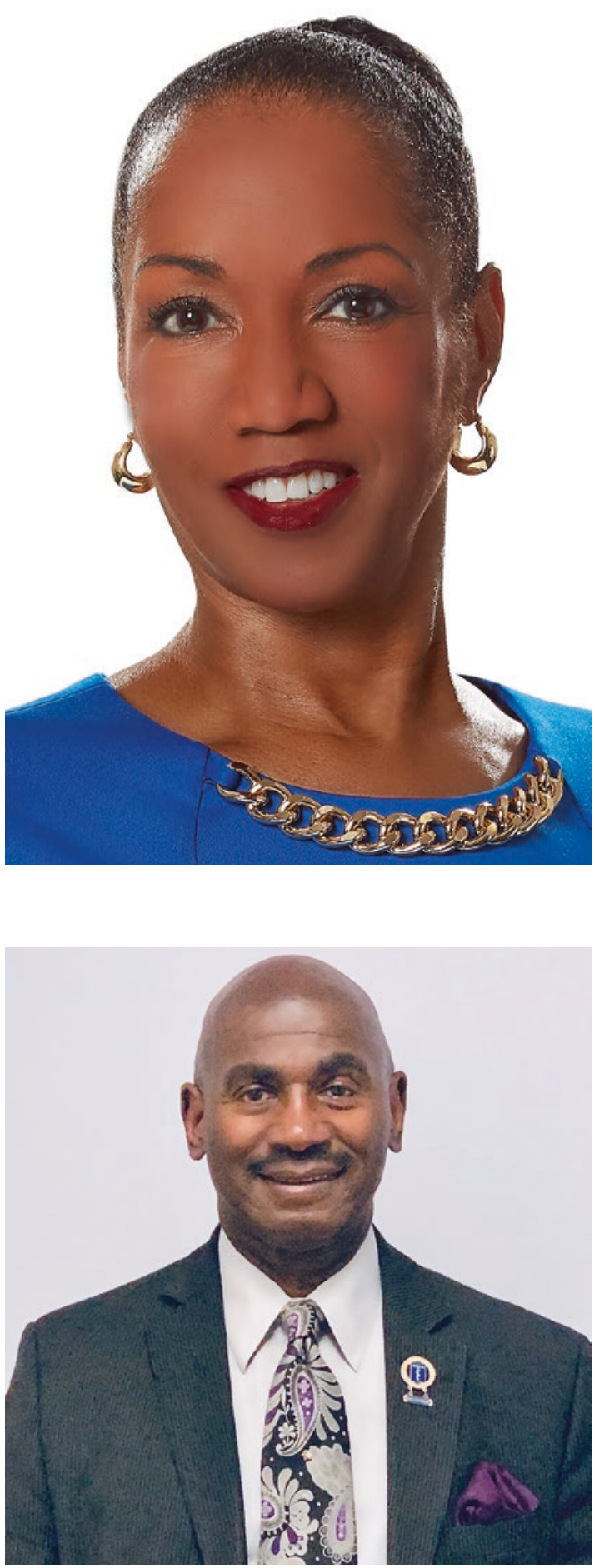
Fig. 6.26 Cedric

M. Bright,

MD. (Photograph courtesy

of Dr. Bright)

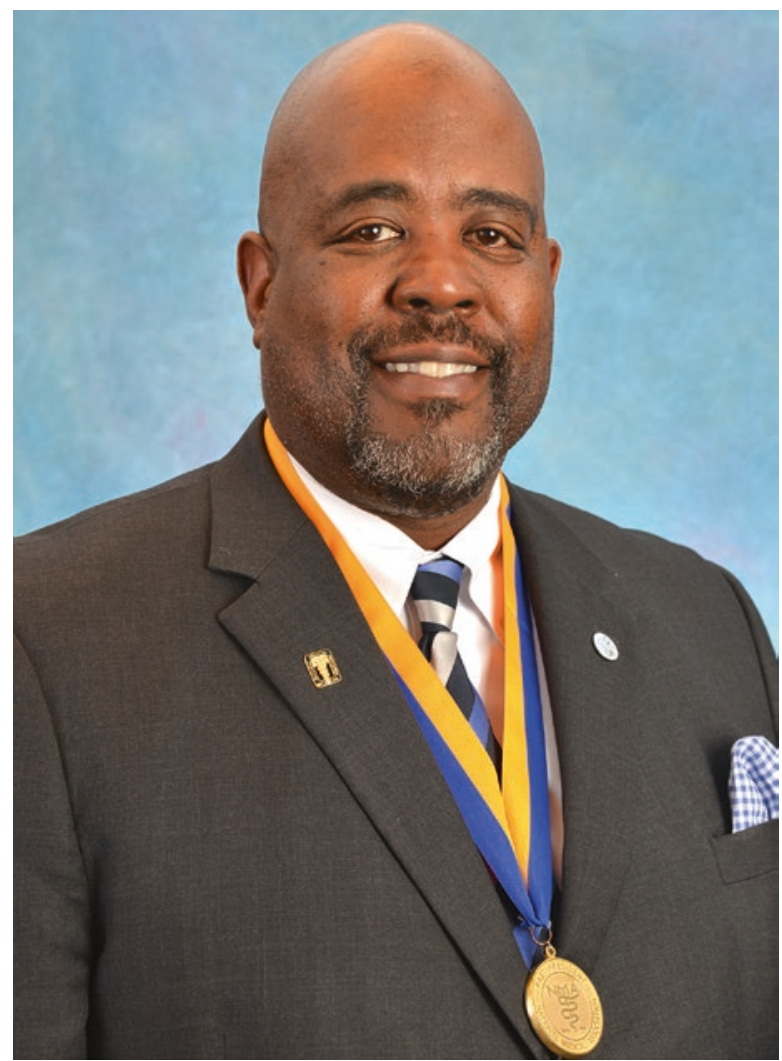

113. Rahn Kennedy Bailey, MD (Fig. 6.27) Undergraduate: Morehouse College. Medical school: University of Texas Medical Branch at Galveston. Postgraduate training: Forensic Psychiatry, Yale School of Medicine. Specialty: Psychiatry. Assistant Dean of Clinical Education, Charles R. Drew University/UCLA. Chief Medical Officer, Kedren Community Health System, Los Angeles. Formerly, Chair of Psychiatry, Wake Forest School of Medicine; formerly Chair of Psychiatry, Meharry Medical College. Chair of the Board of Trustees, W. Montague Cobb/NMA Health Institute. NMA President, 2012.

114. Michael Lenoir, MD (Fig. 6.28). Medical school: University of Texas Medical Branch at Galveston. Specialty: Pediatrics, allergy immunity. Formerly, Director of Allergy Services at San Francisco General Hospital. Associate Clinical Professor in Pediatrics, UC San Francisco. CEO, Ethnic Health American Network, Oakland, CA. NMA President, 2013. 
Fig. 6.27 Rahn Kennedy Bailey, MD. (Photograph courtesy of Dr. Bailey)

Fig. 6.28 Michael Lenoir, MD. (Photograph courtesy of Dr. Lenoir)
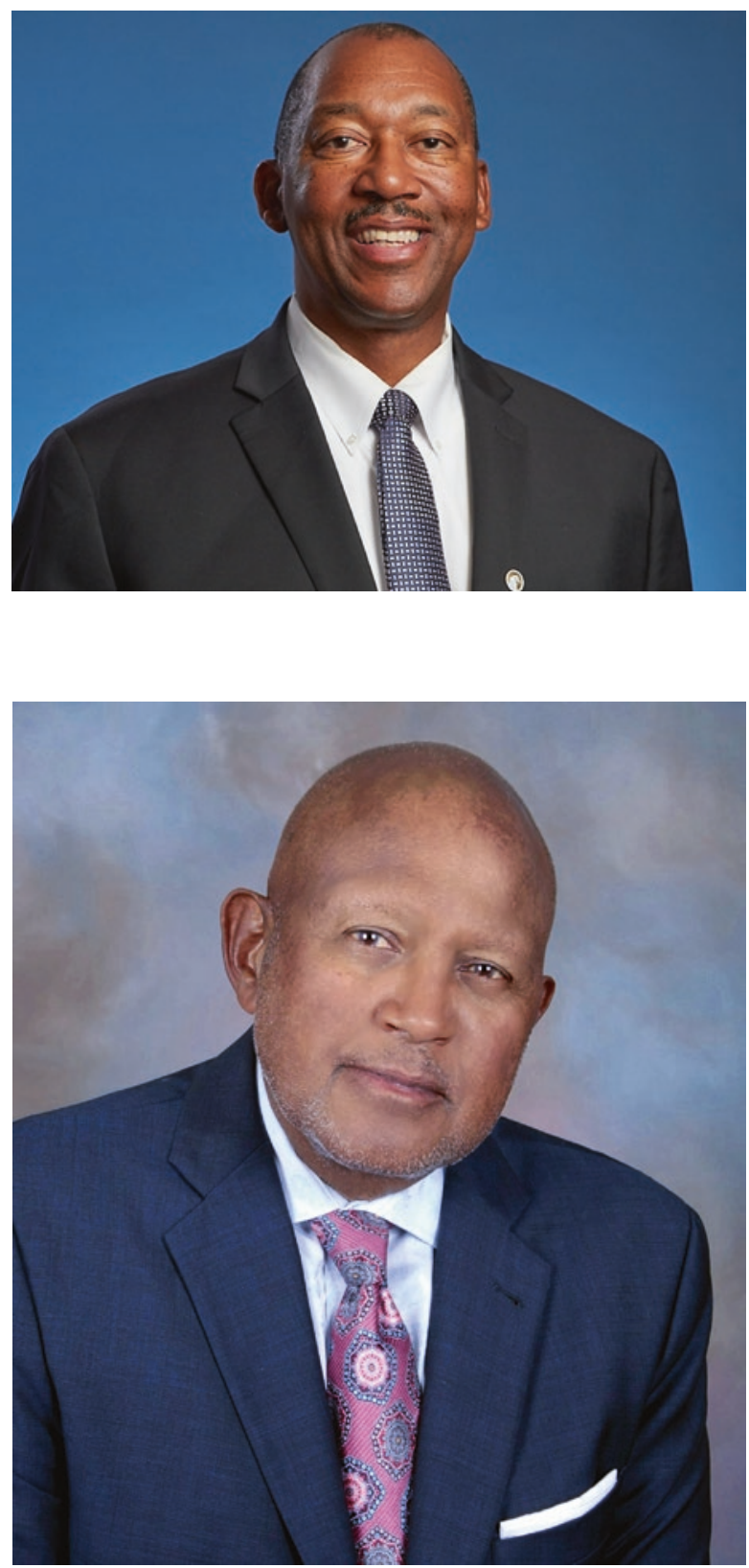
Fig. 6.29 Lawrence L. Sanders, MD, MBA. (Photograph courtesy of the National Medical Association)

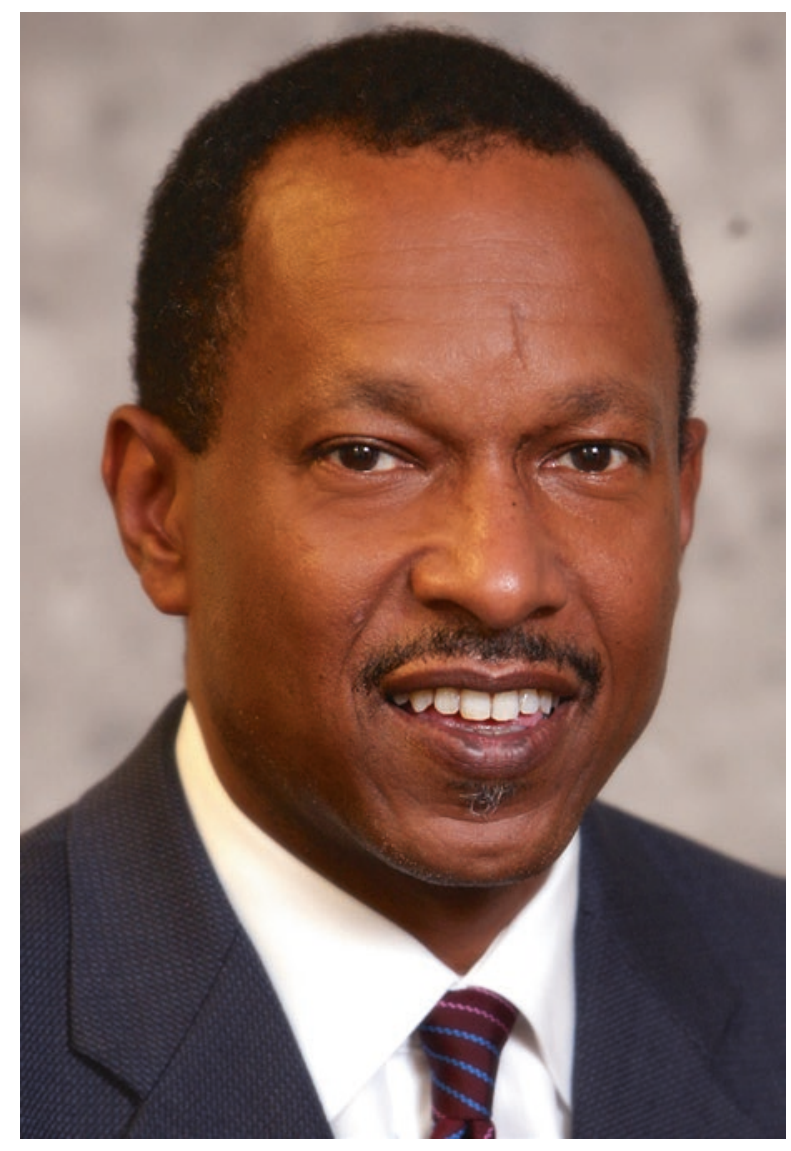

115. Lawrence L. Sanders, MD, MBA. Undergraduate: Clemson University, Clemson, SC. Medical school: Vanderbilt University, Nashville, TN. Specialty: Internal medicine. Associate Professor of Medicine, Morehouse School of Medicine, Grady Memorial Hospital, Atlanta GA. NMA President, 2014 (Fig. 6.29).

116. Edith P. Mitchell, MD (Fig. 6.30) Undergraduate: Tennessee State University, Nashville, TN. Medical school: Medical College of Virginia. Specialty: Medical oncology. Clinical Professor of Medicine and Medical Oncology, Sidney Kimmel Medical College at Thomas Jefferson Medical College, Philadelphia, PA. Director, Center to Eliminate Disparities, and Associate Director, Diversity Affairs, Sidney Kimmel Cancer Center at Thomas Jefferson Medical College. NMA President, 2015.

117. Richard Allen Williams, MD (Fig. 6.31). Undergraduate: Harvard University, graduated cum laude. Medical school: State University of New York (SUNY) Downstate Medical Center. Residencies: UC San Francisco Medical Center 
Fig. 6.30 Edith

P. Mitchell,

MD. (Photograph courtesy

of Dr. Mitchell)

Fig. 6.31 Richard Allen

Williams,

MD. (Photograph courtesy of Dr. Williams)
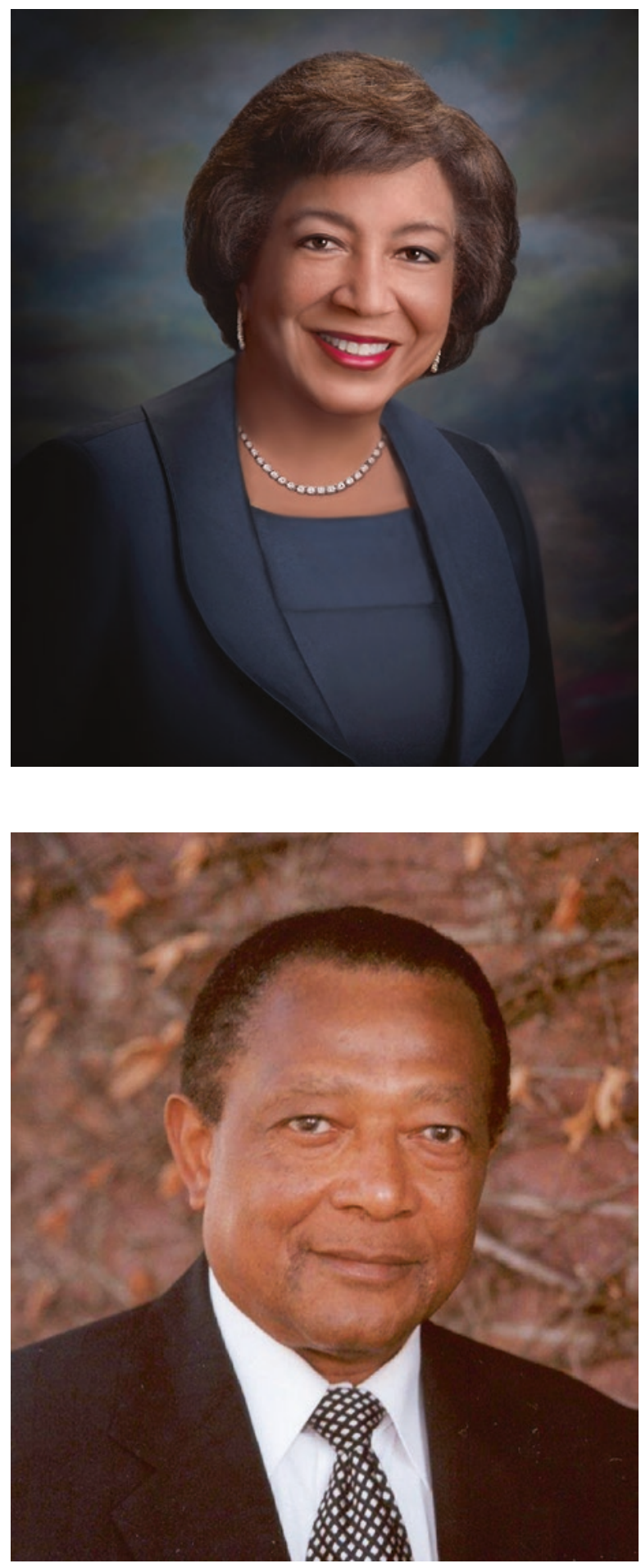
and LA County/USC Medical Center. Postgraduate: Brigham and Women's Hospital and Harvard Medical School; Oxford Round Table, England. Specialty: Cardiology. Clinical Professor of Medicine, UCLA School of Medicine. Former Instructor in Medicine, Harvard Medical School; Junior Associate in Medicine, Brigham and Women's Hospital. Former Head of Cardiology, West Los Angeles VA/UCLA Medical Center. Founder, Association of Black Cardiologists. Founder, President, and CEO, The Minority Health Institute. Author, Textbook of Black-Related Diseases, the first medical book by a black physician accepted into National Museum of African American History and Culture (Smithsonian Institution), and eight other books including Blacks in Medicine (Springer Nature, 2020). NMA President, 2016.

118. Doris Browne, MD, MPH (Fig. 6.32). Undergraduate: Tougaloo College, Tougaloo, MS. Medical school: Georgetown University, Washington, DC. Postgraduate: MPH, UCLA School of Public Health (Community Medicine). Specialty: Hematology/oncology. President and CEO, Browne and Associates, LLC. Formerly, Senior Scientific Program Director, National Cancer Institute; Deputy Medical Research and Development, US Army. NMA President, 2017.

119. Niva Lubin-Johnson, MD (Fig. 6.33). Undergraduate: Creighton University, Omaha, NE. Medical school: Southern Illinois School of Medicine. Specialty: Internal medicine. Senior Attending Physician, Mercy Hospital and Medical

Fig. 6.32 Doris Browne, MD, MPH. (Photograph courtesy of Dr. Browne)

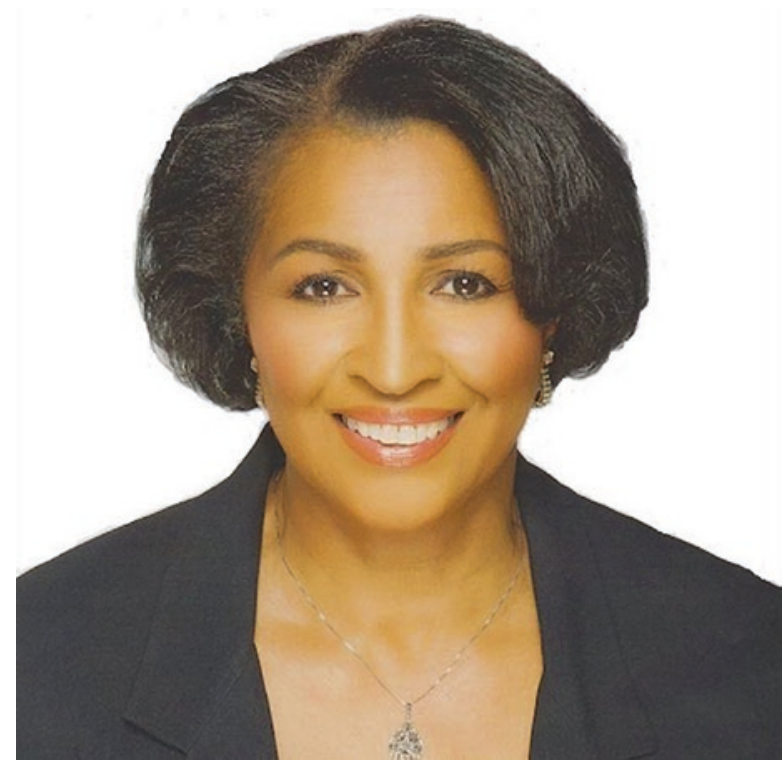


Fig. 6.33 Niva LubinJohnson, MD. (Photograph courtesy of Dr.

Lubin-Johnson)

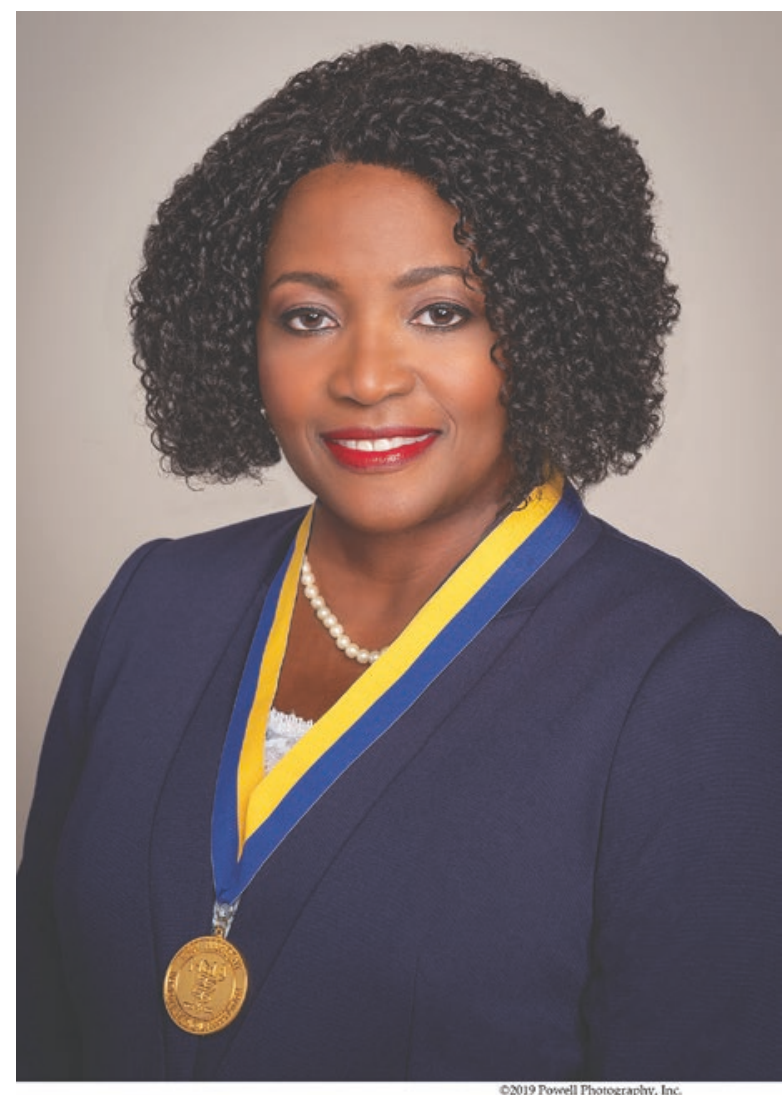

O2019 Powell Photography, Inc.

Center, Chicago IL. Clinical Instructor, University of Illinois. NMA President, 2018.

120. Oliver T. Brooks, MD (Fig. 6.34). Undergraduate: Morehouse College. Medical school: Howard University College of Medicine. Specialty: Pediatrics and adolescent medicine. Medical Director, Pediatric and Adolescent Medicine, Watts Healthcare Corporation, Los Angeles. Medical Director, Jordan and Locke High School Wellness Centers. Medical Director, LA Care Health Plan. Vice-Chair of the Obstetrics/Pediatrics Department, Martin Luther King, Jr. Community Hospital in South Los Angeles. NMA President, 2019. 
Fig. 6.34 Oliver

T. Brooks,

MD. (Photograph courtesy of the National Medical

Association)

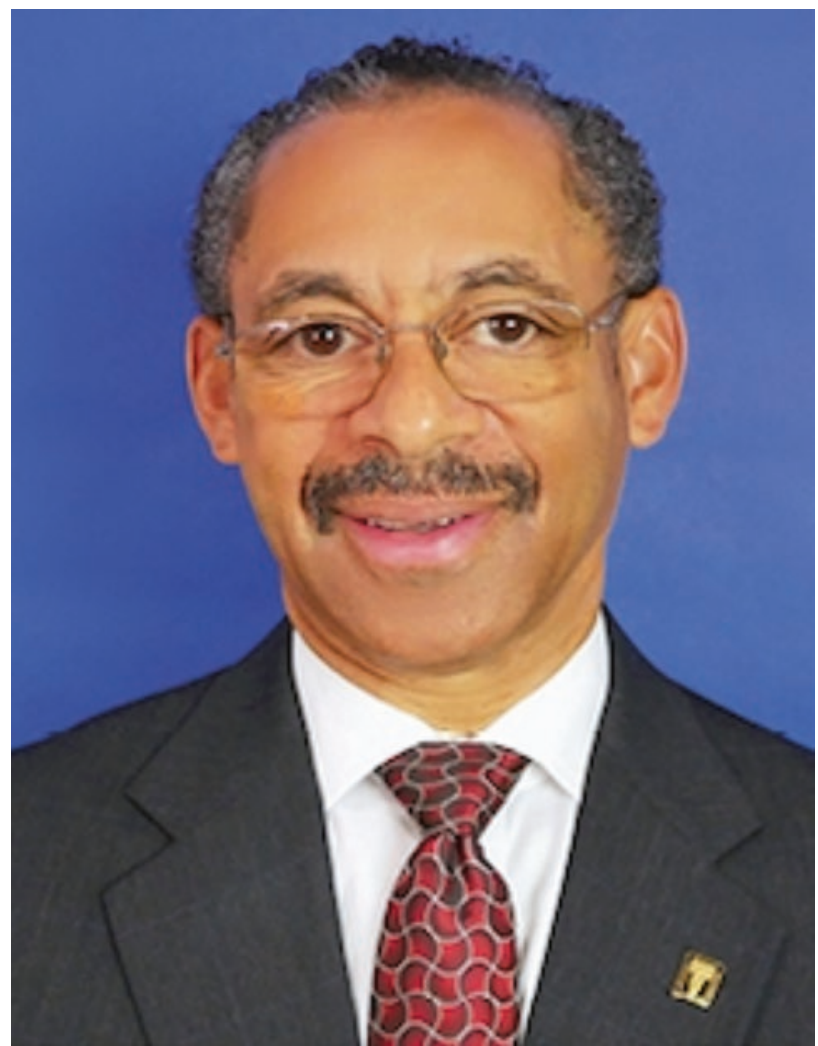

\section{Additional Members of the Honor Roll of Distinguished African American Physicians and Other Healthcare Professionals}

1. Joycelyn Elders, MD, MS (Fig. 6.35). 15th US Surgeon General. First African American and the second woman to head the US Public Health Service. First person to be board certified in pediatric endocrinology in the state of Arkansas. Growing up on a farm in rural poverty, she worked the fields while attending segregated schools. Earned a scholarship to the black liberal arts Philander Smith College, Little Rock, scrubbing floors to pay tuition. Joined the US Army, trained in physical therapy at the Brooke Army Medical Center at Fort Sam Houston, Texas. Enrolled at the University of Arkansas Medical School, Little Rock, on the GI Bill. Internship in pediatrics at the University of Minnesota; residency at University of Arkansas; chief resident in charge of the all-white, all-male residents and interns. Earned an MS in biochemistry and became assistant professor of pediatrics in 1971 and full professor in 1976. Governor William Clinton appointed her head of the Arkansas Department of Health in 1987 and, when he gained the presidency, appointed 
Fig.6.35 M. Joycelyn Elders, MD. (Photograph courtesy of the National Institutes of Health)

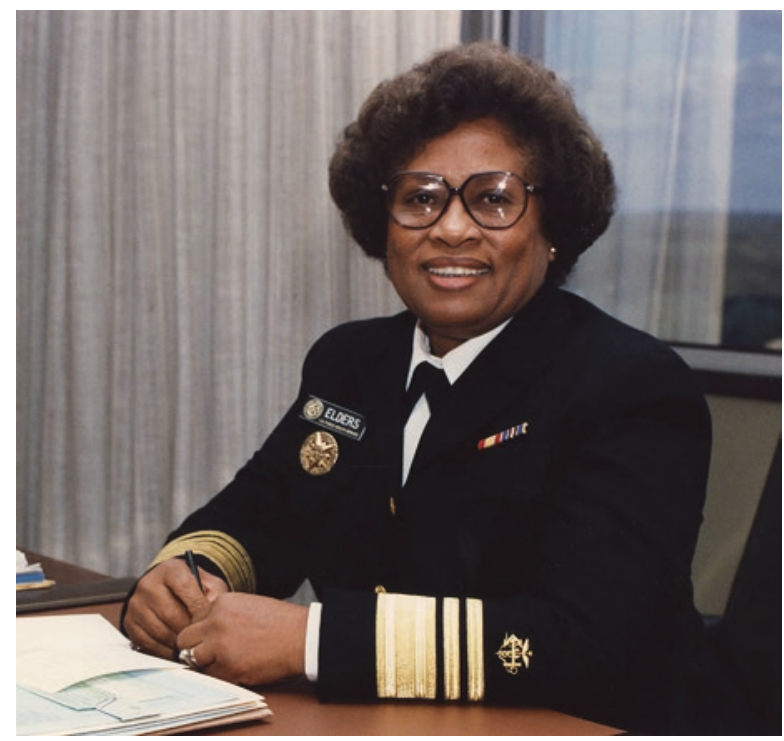

her US Surgeon General in 1993. Returned to the University of Arkansas as a faculty researcher and professor of pediatric endocrinology. Autobiography: Joycelyn Elders, MD: From Sharecropper's Daughter to Surgeon General of the United States of America (1996). Now professor emeritus at the University of Arkansas School of Medicine, she remains active in public health education [7].

2. David Satcher, MD, PhD (Fig. 6.36). 16th US Surgeon General. Undergraduate: Morehouse College. Medical school and postgraduate (PhD, Cytogenetics): Case Western Reserve University, Cleveland, OH. Administrative and faculty positions at the Charles R. Drew Postgraduate Medical School, the King-Drew Sickle Cell Center, and UCLA's School of Public Health, Los Angeles, CA. Former Chair of the Department of Community Medicine and Family Practice at Charles R. Drew University of Medicine and Science and served as President of Drew University, Meharry Medical College, and Morehouse School of Medicine, the only African American physician to serve as president of three medical schools in succession. Appointed director of the Centers for Disease Control and Prevention (CDC) in 1993. Appointed by President Clinton as US Surgeon General in 1998, served concurrently as Assistant Secretary for Health, US Department of Health and Human Services. Currently, Founding Director and Senior Advisor, Satcher Health Leadership Institute, Department of Community Health and Preventive Medicine, Morehouse School of Medicine [8].

3. Regina Benjamin, MD, MBA (Fig. 6.37). 18th US Surgeon General. Undergraduate: Xavier University, New Orleans, LA; Medical school: University of Alabama, Birmingham. Postgraduate: MBA, Tulane University, New Orleans, LA. Served as Associate Dean for Rural Health at the University 
Fig. 6.36 David Satcher, MD, PhD. (Photograph courtesy of the U.S. Public Health Services)

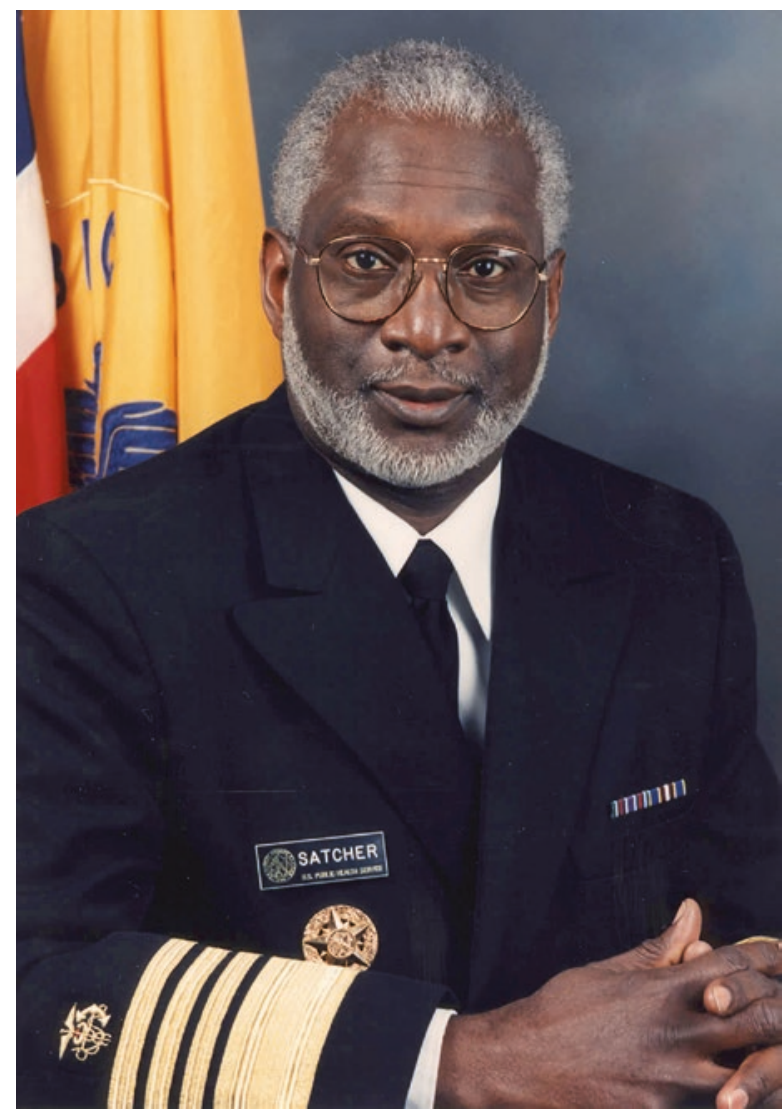

of South Alabama and Director of the Alabama Area Health Education Center, which provides educational opportunities and mentoring to area medical students. Appointed US Surgeon General by President Barack Obama in 2009. Founder and CEO of the rural BayouClinic in Bayou La Batre, LA, serving the underserved in a small fishing village on the Gulf Coast of Alabama, where $80 \%$ of the citizens live below the poverty level. Currently occupies an endowed chair in health sciences at her alma mater, Xavier University. Founder of Gulf States Health Policy Center in Bayou La Batre, working to improve health outcomes in the Gulf States [9].

4. Vice Admiral Jerome M. Adams, MD, MPH (Fig. 6.38). 20th US Surgeon General, Medical school: Indiana University School of Medicine, Indianapolis, IN. Postgraduate: MPH (Chronic Disease Prevention), UC Berkeley. Specialty: Anesthesiology. Holds the rank of Vice Admiral in the US Public Health Service. Indiana Health Commissioner and faculty member of Indiana University. Appointed US Surgeon General by President Donald Trump in 2017. Recognized as a leading expert in the substance abuse crisis, and has pledged to combat the opioid crisis confronting the nation [10]. Has taken a leading role in combating the coronavirus crisis facing the United States. 
Fig. 6.37 Regina Benjamin, MD, MBA. (Photograph courtesy of the Department of Health and Human Services)

Fig. 6.38 Vice Admiral Jerome M. Adams, MD, MPH. (Courtesy U.S. Public Health Service)
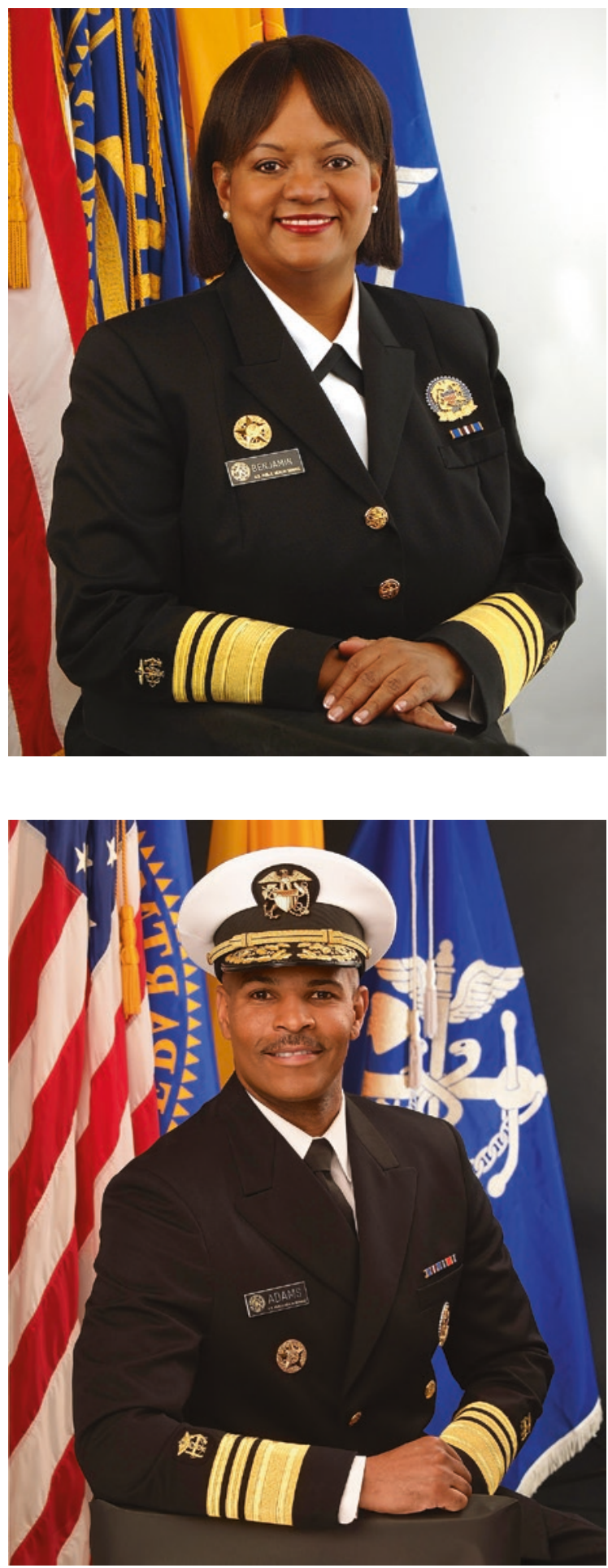
5. Louis W. Sullivan, MD (Fig. 6.39). Undergraduate: Morehouse College. Medical school: Boston University School of Medicine. Postgraduate training: New York Hospital_Cornell Medical Center, Massachusetts General Hospital, and Thorndike Memorial Laboratory of Harvard Medical School, Boston City Hospital. Specialties: Internal medicine and hematology. As secretary of the US Department of Health and Human Services in the President George H.W. Bush administration (1989-1993), launched Healthy People 2000 (a blueprint for health promotion/disease prevention), campaigned against tobacco, promoted the use of seat belts in vehicles, and improved FDA food labels. Prominent researcher in hematology at Boston University and at Harvard. Founding Dean and President of the Morehouse School of Medicine. Currently, Chair and CEO of the Sullivan Alliance to Transform the Health Professions, Washington, DC [11].

6. Claude H. Organ, MD (1926-2005) (Fig. 6.40). Undergraduate: Xavier University. Medical school: Creighton University School of Medicine. General surgeon, educator, and author (A Century of Black Surgeons: The USA Experience). First African American to head the surgical department at Creighton (Professor and Chair, 1971). Later also Professor at the University of Oklahoma and at UC Davis. A founder of the Society of Black Academic Surgeons. The second black president of the American College of Surgeons.

Fig. 6.39 Louis

W. Sullivan,

MD. (Photograph courtesy of the National Library of Medicine)

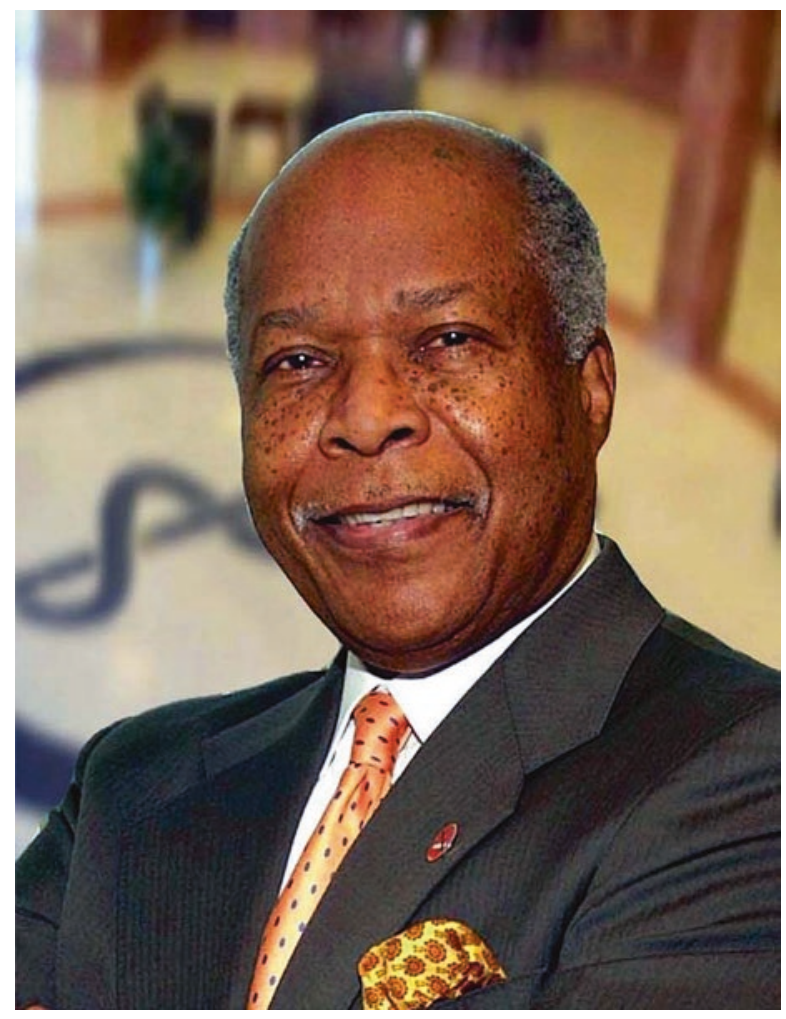


Fig. 6.40 Claude H. Organ,

MD. (Photograph courtesy of the Organ family)

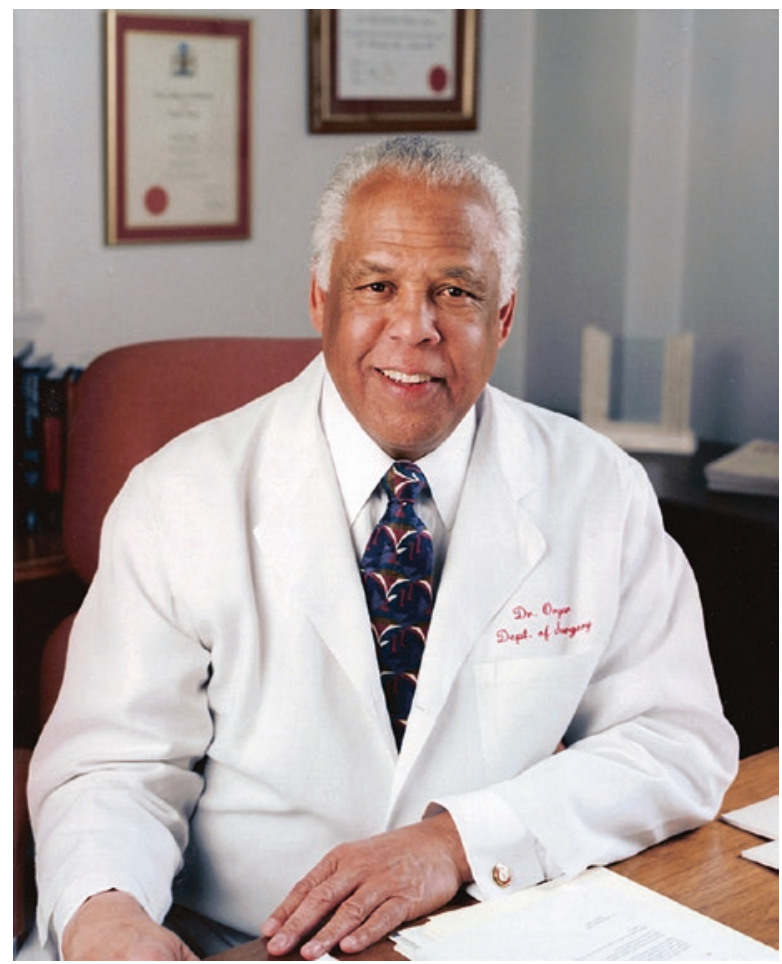

Member of the editorial board of JAMA and the first African American editor of the Archives of Surgery. Only male to receive the Nina Starr Braunwald Award (1993) from the Association of Women Surgeons for "outstanding service to the advancement of women in surgery."

7. Lasalle D. Leffall, Jr., MD (1930-2019) (Fig. 6.41). Undergraduate: BS (summa cum laude) Florida A\&M University, Tallahassee. Medical school: Howard University College of Medicine. Fellowship: Surgical oncology, Memorial Sloan Kettering Cancer Center, New York City, remaining there before serving in the US Army Medical Corps (Chief of General Surgery, US Army Hospital in Munich, Germany, 1960-1961). Late distinguished Charles R. Drew Professor and Chair of the Department of Surgery at Howard University College of Medicine. The first African American to be President of the American College of Surgeons and of the American Cancer Society. First African American to be President of the following professional societies: American Cancer Society, where he focused needed attention on the disparities in cancer incidence, diagnosis, treatment, and mortality among African Americans; Society of Surgical Oncology; and the American College of Surgery. Member of Alpha Omega Alpha Honor Medical Society. Awarded Howard's prestigious Faculty Award, their highest academic honor, over 30 times, which is unprecedented in the university's 150-year history. Published memories: No Boundaries: A Cancer Surgeon's Odyssey (2005). 
Fig. 6.41 Lasalle

D. Leffall, Jr.,

MD. (Courtesy of the

National Library of

Medicine, with permission

from the Leffall family)

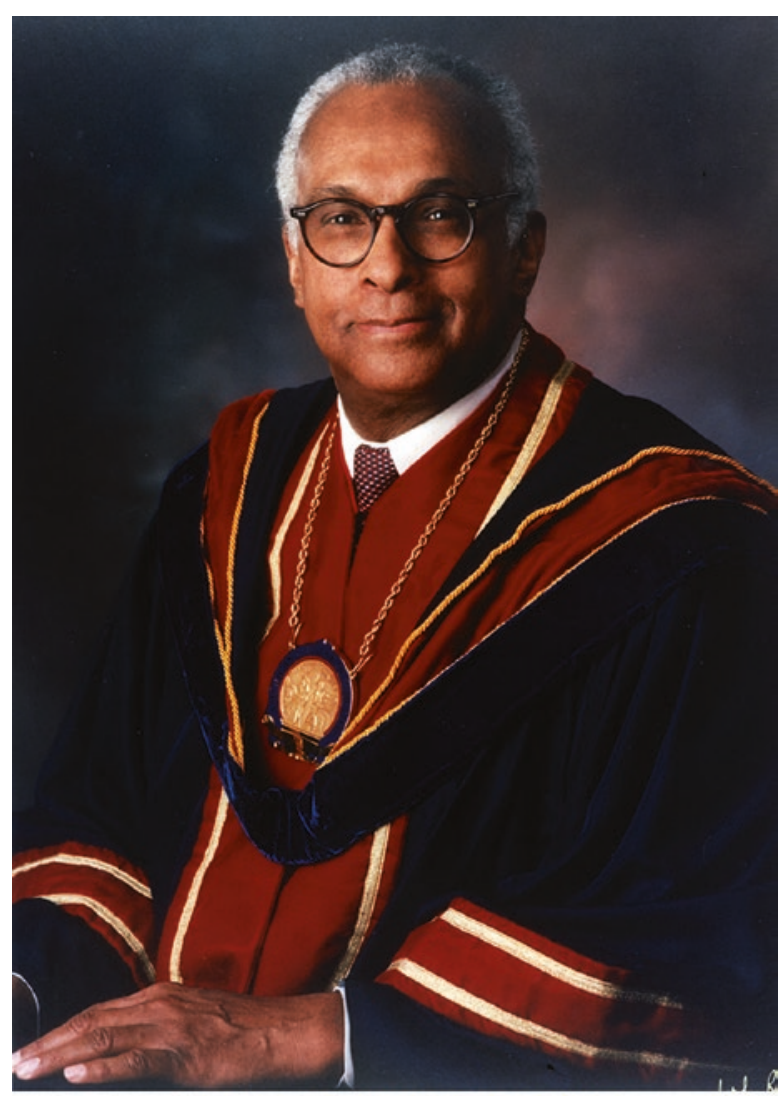

Courtesy LaSalle D. Leffall, Jr., M.D.

8. Keith L. Black, MD (Fig. 6.42). College and medical school: University of Michigan. Specialty: Neurosurgery. Former Head of the UCLA Comprehensive Brain Tumor Program. Currently Chair of Neurosurgery and Director of the Maxine Dunitz Neurosurgical Institute at Cedars Sinai Medical Center in Los Angeles. Research focuses on biology of blood-brain barrier and biochemical modulation of the blood-brain tumor barrier, targeted drug delivery, tumor immunology, cancer vaccines, cancer stem cells, microwave tumor ablation, nanotechnology for drug delivery, optical guided surgery for brain tumors, and Alzheimer's retinal imaging.

9. Ludlow B. Creary, MD, MPH (Fig. 6.43). Undergraduate: Long Island University, Brooklyn, NY. Medical school: Howard University College of Medicine. Postgraduate: MPH, Fielding School of Public Health at UCLA. Professor and inaugural Chair, Department of Family Medicine, Charles R. Drew University of Medicine and Science/UCLA for more than two decades. One of the founders of the Dr. Martin Luther King, Jr. Community Hospital in Watts. Distinguished Service Award from the National Medical Association and the Legacy Award from National Medical Fellowships. Inducted into the Hall of Fame at the Fielding School of Public Health at UCLA in 2019. President of the philanthropic Creary Family Foundation. 
Fig. 6.42 Keith L. Black, MD. (Photograph @The Beverly Hills

Photographer, courtesy of Kareem Assassa)

Fig. 6.43 Ludlow B. Creary, MD, MPH. (Photograph courtesy of Dr. Creary)
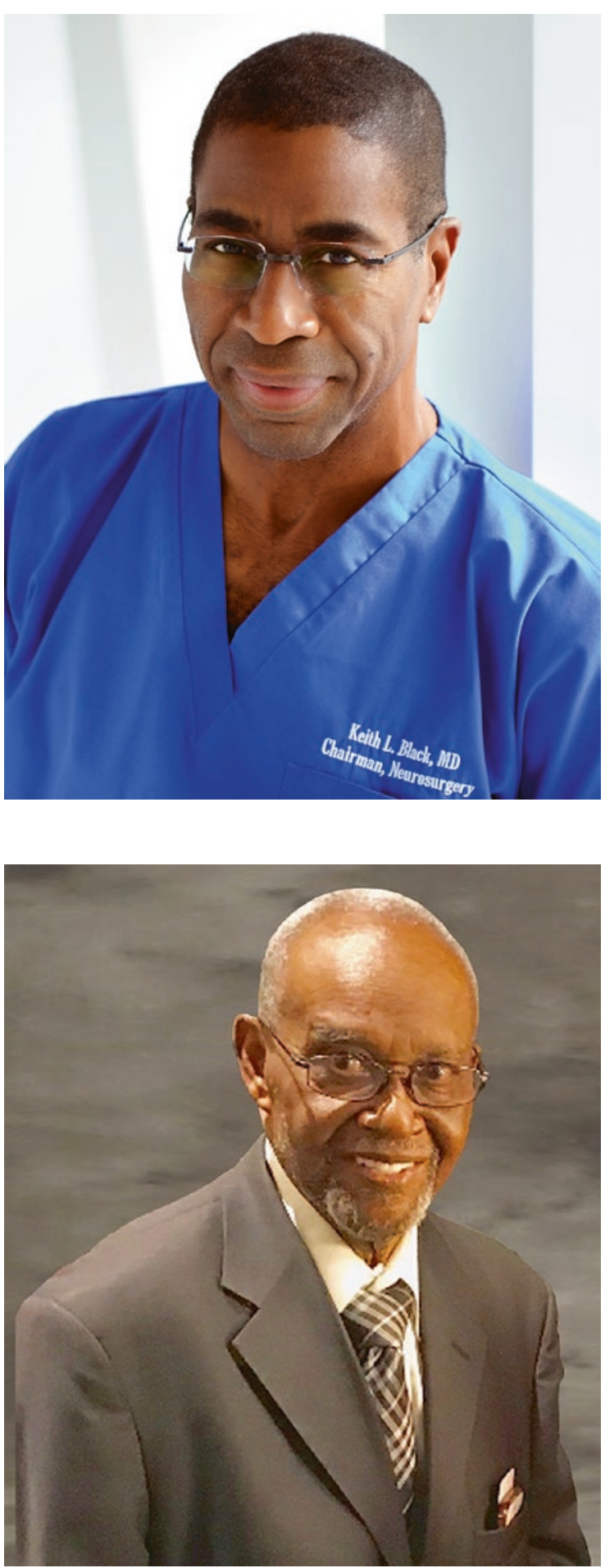
10. Fred D. Parrott, MD (Fig. 6.44). Undergraduate: Howard University. Medical school: Meharry Medical College. Postgraduate: University of Minnesota. Specialty: Obstetrics/gynecology. Established the Real Men Cook Foundation for Education in 1984 and the Real Men Cook Foundation for Early Detection of Prostate Cancer in 1994. Major contributor to the medical schools of Historically Black Colleges and Universities (HBCU). 2020 Legacy Award from National Medical Fellowships.

11. Augustus A. White III, MD, PhD (Fig. 6.45). Undergraduate: Brown University. Medical school: Stanford University, Palo Alto CA. Postgraduate: Residency, Orthopedic surgery, Yale University School of Medicine; PhD, Orthopedic Biomechanics, Karolinska Institute, Stockholm, Sweden. Professor of Orthopedic Surgery at Harvard Medical School for 41 years. Notable for his contributions to the delivery of equitable humane healthcare. Received the Bronze Star for his service as a military surgeon in Vietnam and the Distinguished Service Award from the NMA. Currently the Ellen and Melvin Gordon Distinguished Professor of Medical Education and Professor of Surgery at Harvard Medical School.

12. Charles H. Epps, Jr., MD (Fig. 6.46). Medical school: Howard University College of Medicine. Specialty: Orthopedic surgery with a focus on children with insufficient limbs. Taught thousands of students and residents. Former

Fig. 6.44 Fred D. Parrott, MD. (Photograph courtesy of Dr. Parrott)

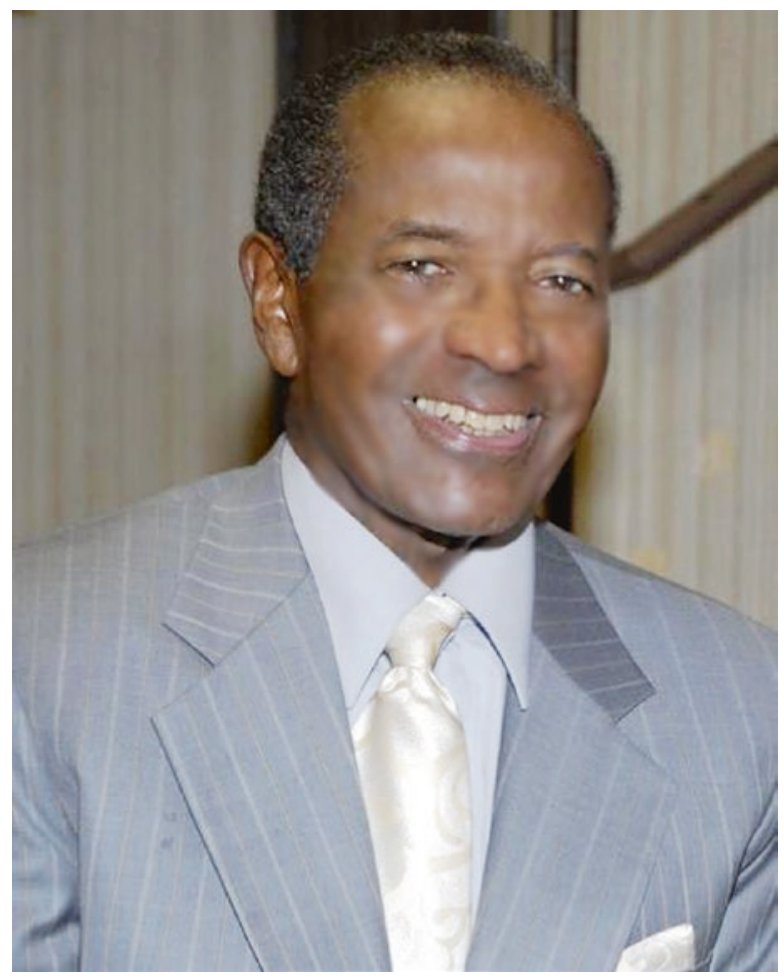


Fig. 6.45 Augustus

A. White III, MD,

$\mathrm{PhD}$. (Photograph courtesy of Dr. White)

Fig. 6.46 Charles H. Epps, Jr.,

MD. (Photograph courtesy of daughter Roselyn

E. Epps, MD)
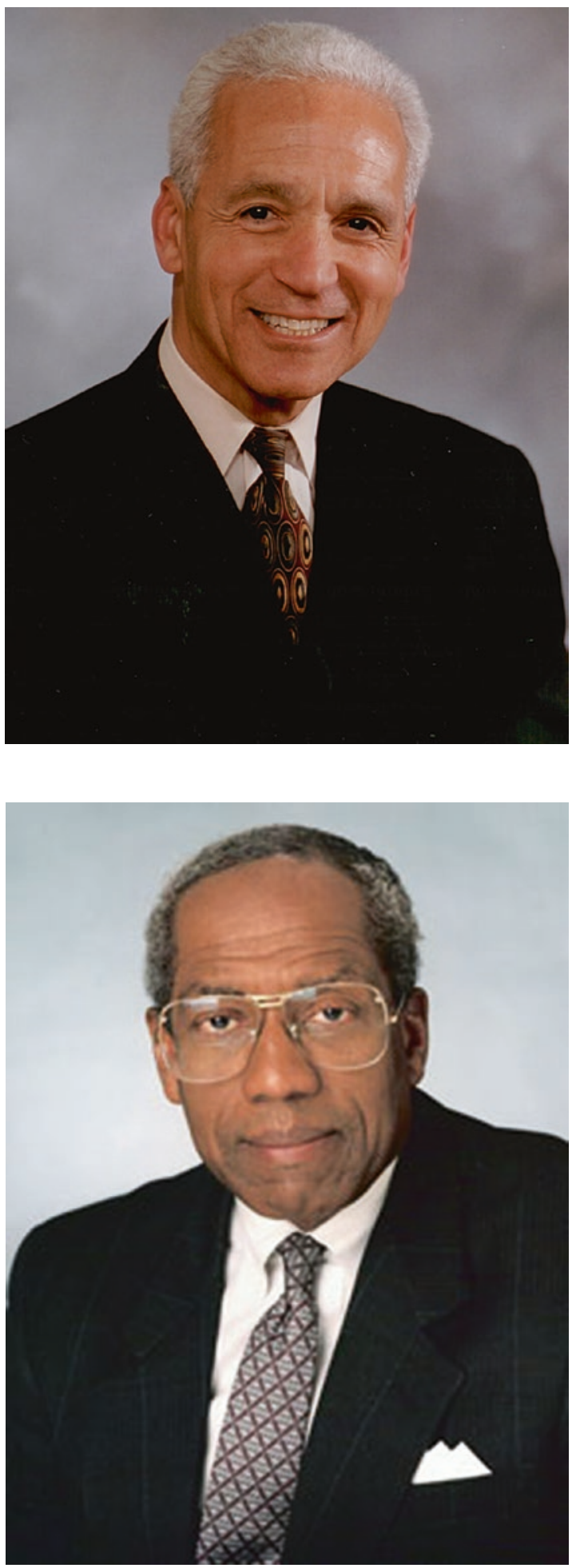
Chair of Orthopedics and former Dean at Howard. First African American President of the American Orthopaedic Association. Publications: Senior editor, African-American Medical Pioneers (1994); editor, Complications in Orthopaedic Surgery, Vols I and II (1986/1994); and co-editor of Complications in Pediatric Orthopaedic Surgery, (1994).

13. Roselyn Payne Epps, MD, MPH, MA (Fig. 6.47). Undergraduate and medical school: Howard University. Postgraduate: MPH, Johns Hopkins University, Baltimore, MD; MA Interdisciplinary Studies, American University, Washington, DC. Specialties: Pediatrics and public health. Former Commissioner of Public Health for Washington, DC. First African American woman President of the American Academy of Pediatrics in DC and first African woman President of the American Medical Women's Association. Under the auspices of the American Medical Women's Association, senior editor of The Women's Complete Healthbook (1995), one of the first manuals of its kind.

14. Wayne J. Riley, MD, MPH, MBA (Fig. 6.48). Undergraduate: Yale University. Medical school: Morehouse School of Medicine. Postgraduate: MPH, Tulane University School of Public Health and Tropical Medicine; MBA, Rice University, Houston, TX. Residency: Baylor College of Medicine. Specialty:

Fig. 6.47 Roselyn Payne Epps, MD, MPH, MD. (Photograph courtesy of daughter Roselyn E. Epps, MD)

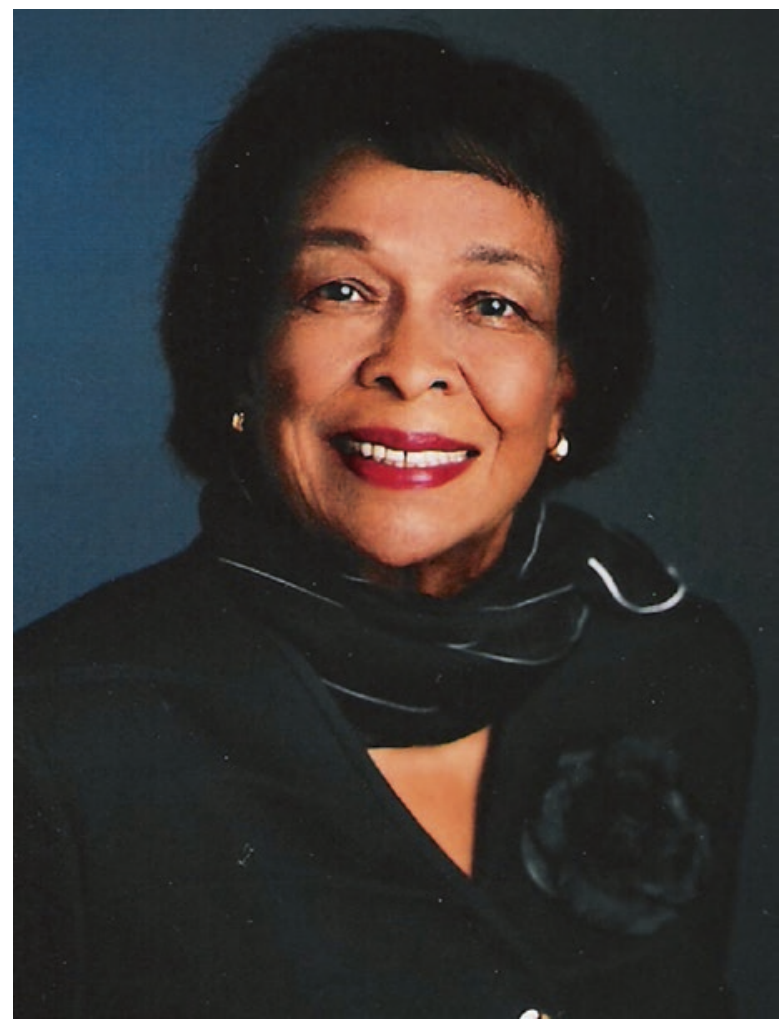


Fig. 6.48 Wayne J. Riley, $\mathrm{MD}, \mathrm{MPH}$,

MBA. (Photograph courtesy of Dr. Riley)

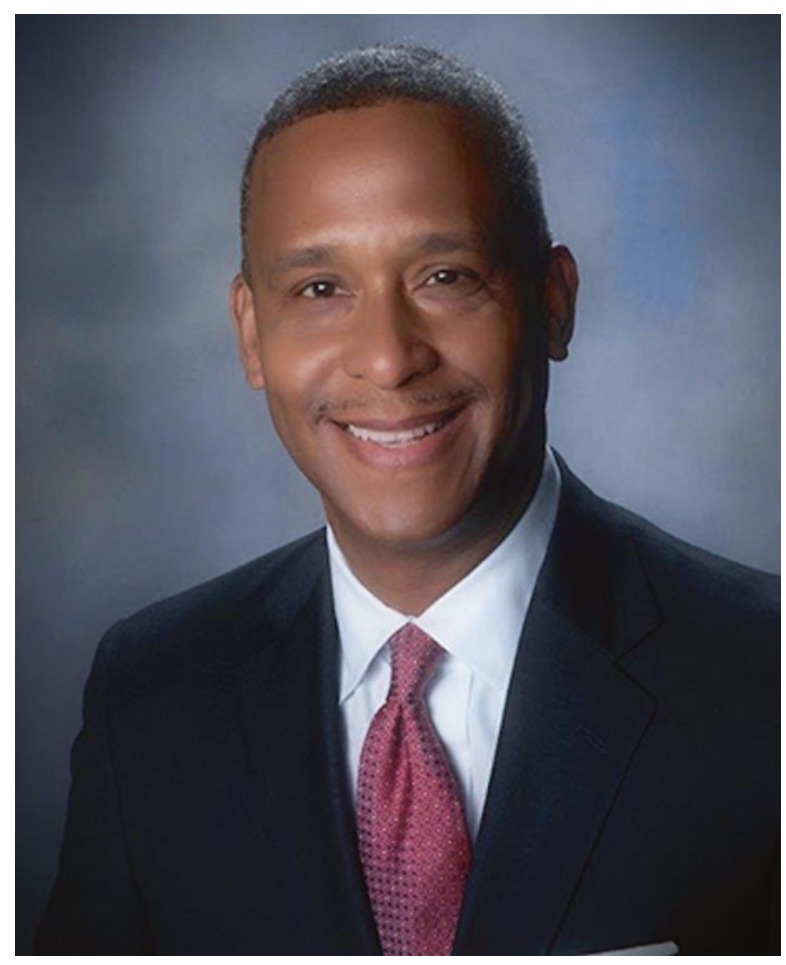

Internal medicine. President Emeritus, American College of Physicians. Member, National Academy of Medicine. Former Chair, Section on the Administration of Health Services, Education, and Research, National Academy of Medicine. Former President, Meharry Medical College. Fellow and Member, Board of Trustees, New York Academy of Medicine; Secretary and Member, Board of Trustees, Arnold P. Gold Foundation. Currently, President, SUNY Downstate Health Sciences University, and Professor of Internal Medicine and Health Policy and Management at SUNY.

15. Lonnie R. Bristow, MD (Fig. 6.49). Undergraduate: Morehouse College and City College of New York. Medical school: New York University. Specialties: Internal medicine, occupational medicine. First African American elected President of the American Medical Association (AMA) (1995-1996). During tenure as Chair of the AMA Board of Trustees, successful in obtaining AMA support for the federal government's plan for healthcare reform put forth by the Clinton Administration. Currently an active member of the National Academy of Medicine, one of three academies that make up the National Academies of Sciences, Engineering, and Medicine in the United States. Received the 2009 NYU Health Science Award. Has articulated a core set of principles regarding patients that he feels every physician is obligated to observe: compassion, competence, courtesy, and honesty. 
Fig. 6.49 Lonnie $\mathrm{R}$ Bristow, MD. (Photograph courtesy of Dr. Bristow)

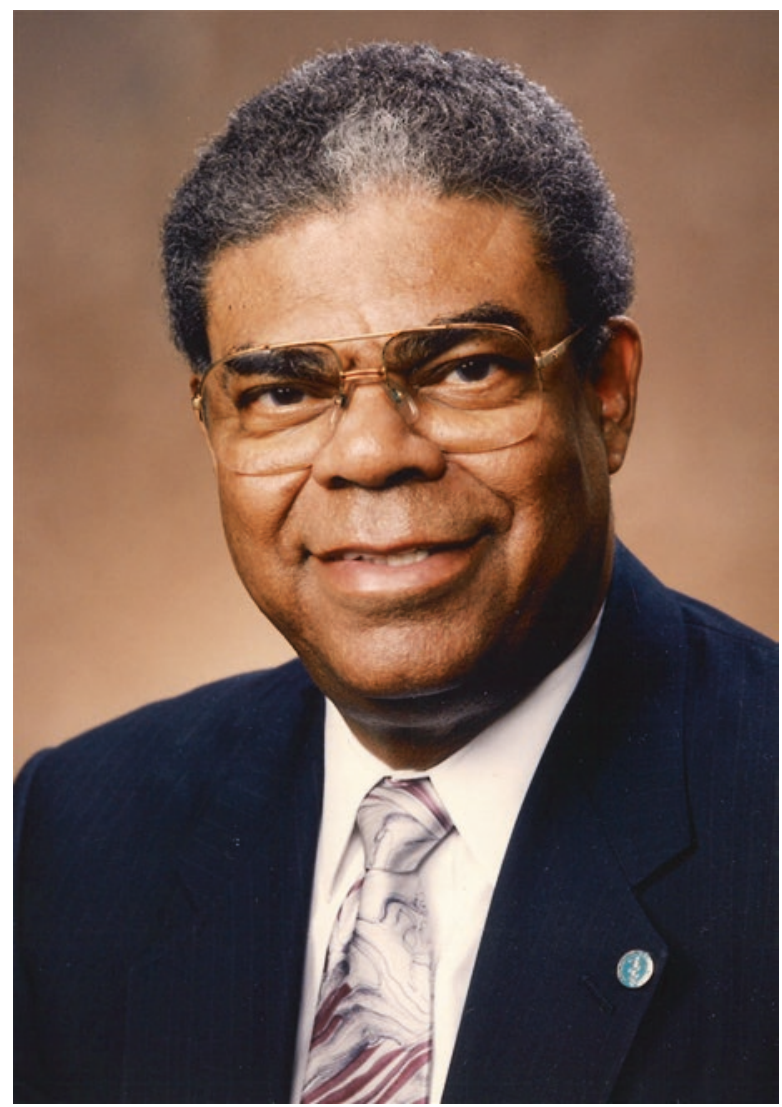

16. Patrice A. Harris, MD, MA (Fig. 6.50). Undergraduate, medical school, postgraduate: West Virginia University, Morgantown, WV. Residency and fellowships: Child, adolescent, and forensic psychiatry, Emory University School of Medicine. Forensic and child/adolescent psychiatrist from Cartersville, GA. Served as Chief Health Officer for Fulton County, GA, where she advanced a program to integrate public and behavioral health and primary care. Adjunct assistant clinical professor at the Morehouse School of Medicine, as well as an adjunct assistant professor in the Emory Department of Psychiatry and Behavioral Sciences. In June 2019, sworn in as the first black woman to lead the AMA. Prior to becoming AMA President, she was a member of the Board of Directors from 2011 and Chair from 2016. Chair of the AMA's Opioid Task Force.

17. Clyde W. Yancy, MD, MSc (Fig. 6.51). Medical school: Tulane University School of Medicine. Vice Dean, Diversity and Inclusion; Magerstadt Endowed Professor of Medicine; Professor of Medical Social Sciences; and Chief of Cardiology at Northwestern University, Feinberg School of Medicine, Evanston, IL. President of the American Heart Association (2009-2010). Author of "The Role of Race in Heart Failure Therapy" (Current Cardiology Reports, 2002). 
Fig. 6.50 Patrice

A. Harris, MD,

MA. (Photograph courtesy

of Dr. Harris)

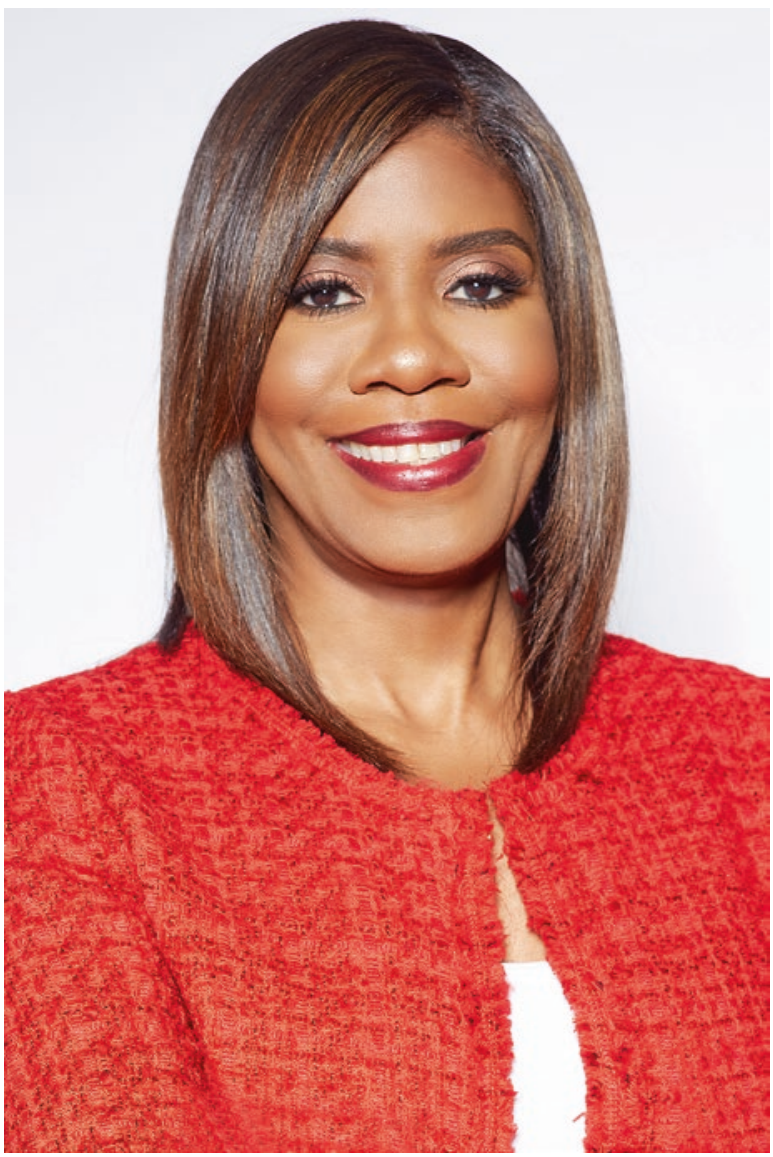

Deputy Editor, JAMA Cardiology; and serves on the editorial boards for Journal of the American College of Cardiology, Circulation, American Heart Journal, and JACC Heart Failure. As a revered and legendary educator and researcher in heart failure, received the Dr. Daniel D. Savage Science Award from the ABC.

18. Kim A. Williams, MD (Fig. 6.52). Undergraduate: University of Chicago. Medical School: University of Chicago Pritzker School of Medicine. Residency and fellowship: Emory University Hospital and the University of Chicago Medical Center. James B. Herrick Professor of Medicine and Chief of the Division of Cardiology at Rush University in Chicago, specializing in prevention and imaging. Has served on numerous national committees and boards, including President of the American College of Cardiology, President of the American Society of Nuclear Cardiology, and Chair of the Board of Directors of the ABC. Founder of the Urban Cardiology Initiative in Detroit, Michigan, to reduce ethnic heart care disparities; continues community-based efforts in Chicago at Rush. Among the world's leaders in cardiac imaging, he received the Dr. Daniel D. Savage Science Award from the ABC. 
Fig. 6.51 Clyde W. Yancy, MD, MSc. (Photograph Courtesy of Dr. Yancy)

Fig. $6.52 \mathrm{Kim}$

A. Williams,

MD. (Photograph courtesy of Dr. Williams)
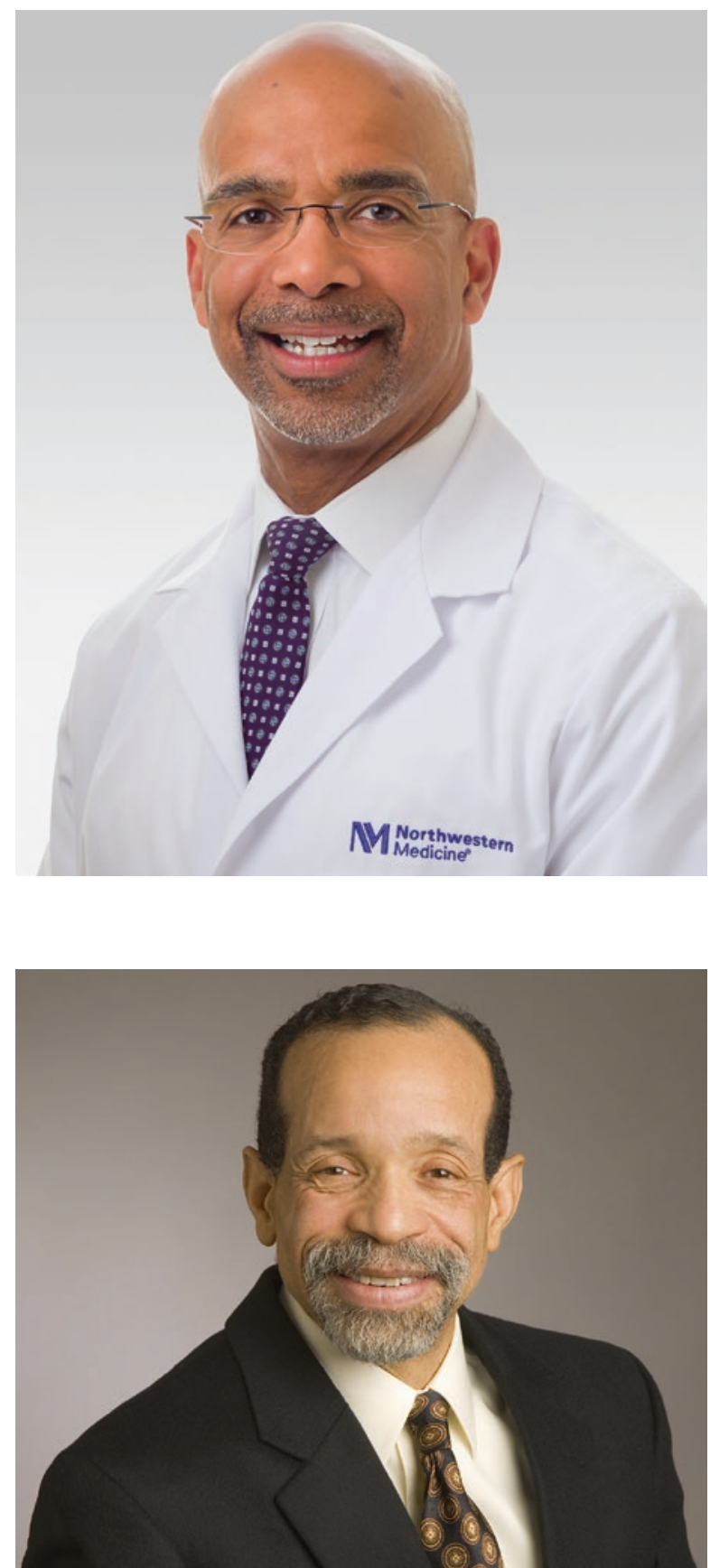
19. James E. K. Hildreth, PhD, MD (Fig. 6.53). Undergraduate: BS Chemistry (magna cum laude) from Harvard University, selected as the first African American Rhodes Scholar from Arkansas. Postgraduate: PhD in Immunology, University of Oxford, Oxford, UK. Medical school: Johns Hopkins School of Medicine where he later became the first African American Full Professor in the basic sciences. A distinguished medical researcher, especially in the fight against HIV/AIDS, he was elected to Institute of Medicine (now known as the National Academy of Medicine, one of three academies that make up the US National Academies of Sciences, Engineering, and Medicine). Former Dean of the College of Biological Sciences at UC Davis and professor in the Departments of Molecular Biology and Internal Medicine at the UC Davis School of Medicine. Currently serves as the 12th President and Chief Executive Officer of Meharry Medical College

20. David M. Carlisle, MD, PhD (Fig. 6.54). Undergraduate: Wesleyan University, Middletown, CT. Medical school: Brown University. Postgraduate: MPH and $\mathrm{PhD}$, Health Services, UCLA Fielding School of Public Health. Robert Wood

Fig. 6.53 James

E. K. Hildreth, PhD, MD. (Photograph courtesy of Dr. Hildreth)

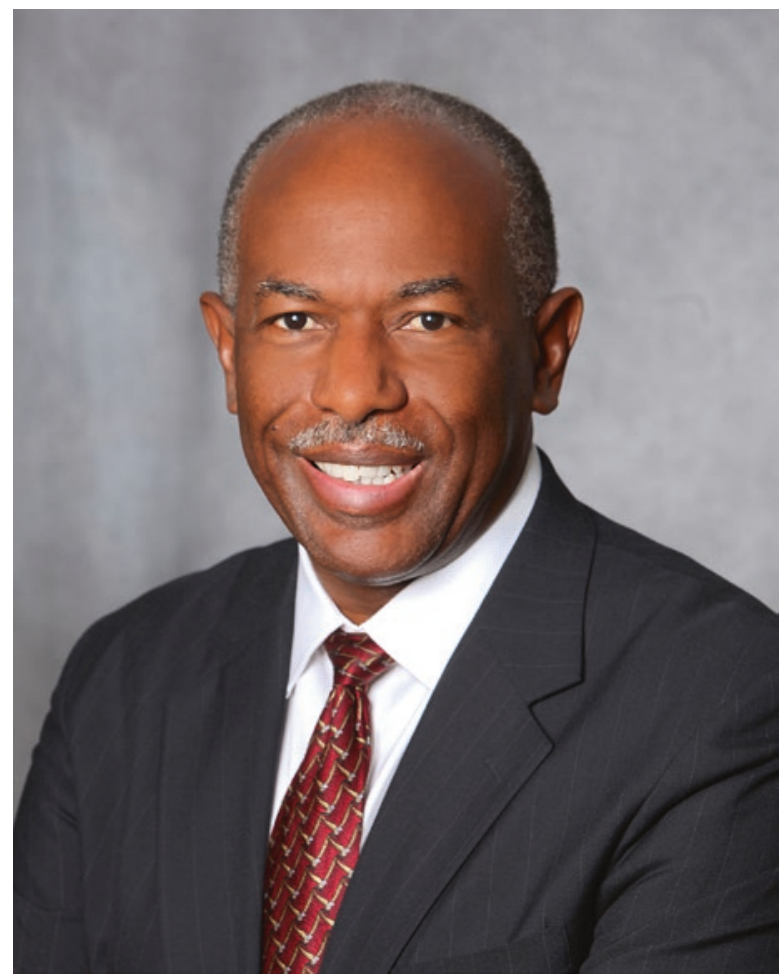


Fig. 6.54 David M. Carlisle, MD,

PhD. (Photograph courtesy

of Dr. Carlisle)

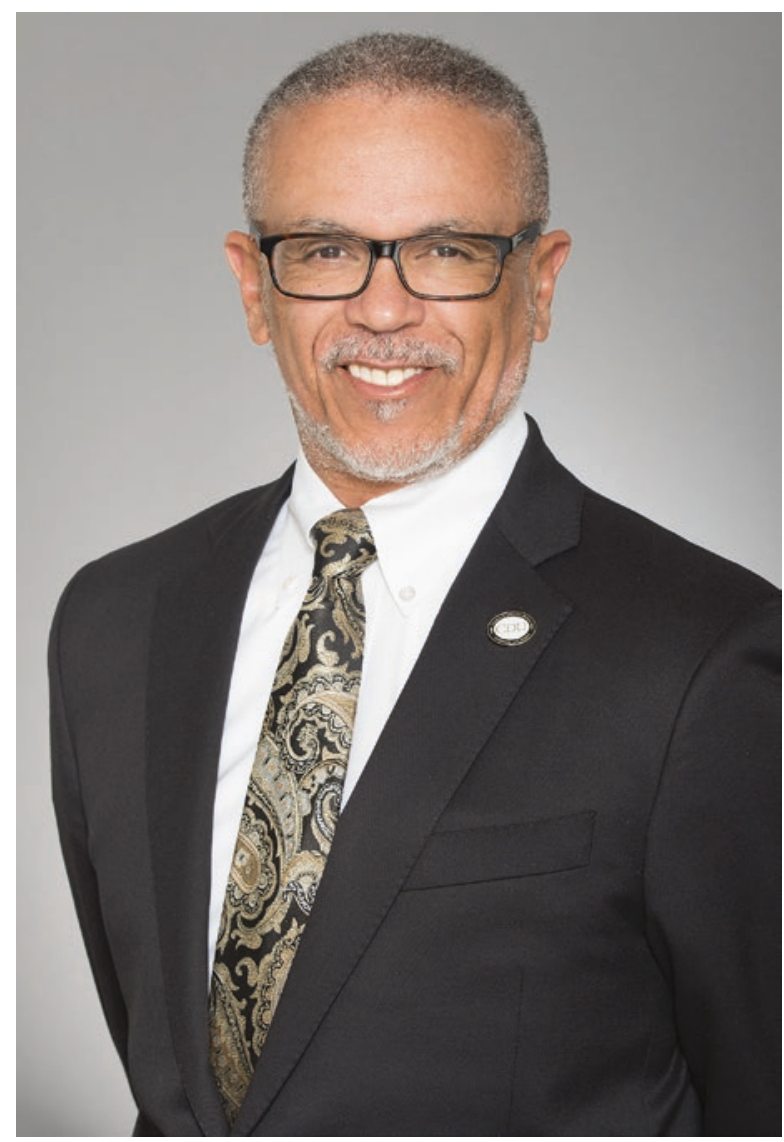

Johnson Foundation Clinical Scholars Program fellowship at the David Geffen School of Medicine at UCLA. Former Director of the Office of Statewide Planning and Development (OSHPD) in California, overseeing its first health disparities report and increased scholarship and repayment opportunities for health providers committed to practice in underserved communities. Currently President and CEO of the Charles R. Drew University of Medicine and Science/ UCLA in Watts, California. Professor of Medicine at Drew University and an Adjunct Professor of Medicine at UCLA.

21. Valerie Montgomery Rice, MD (Fig. 6.55). Undergraduate: Georgia Institute of Technology, Atlanta. Medical school: Harvard Medical School. Residency: Emory University School of Medicine. Expert in obstetrics/gynecology and a distinguished researcher in infertility, focusing on the health problems of women of color, particularly on disproportionate maternal mortality in black women. Was a founding director of the Center for Women's Health Research at Meharry Medical College. Member of the National Academy of Medicine. Currently President and Dean, Morehouse School of Medicine. 
Fig. 6.55 Valerie Montgomery Rice, MD. (Photograph courtesy of Dr. Rice)

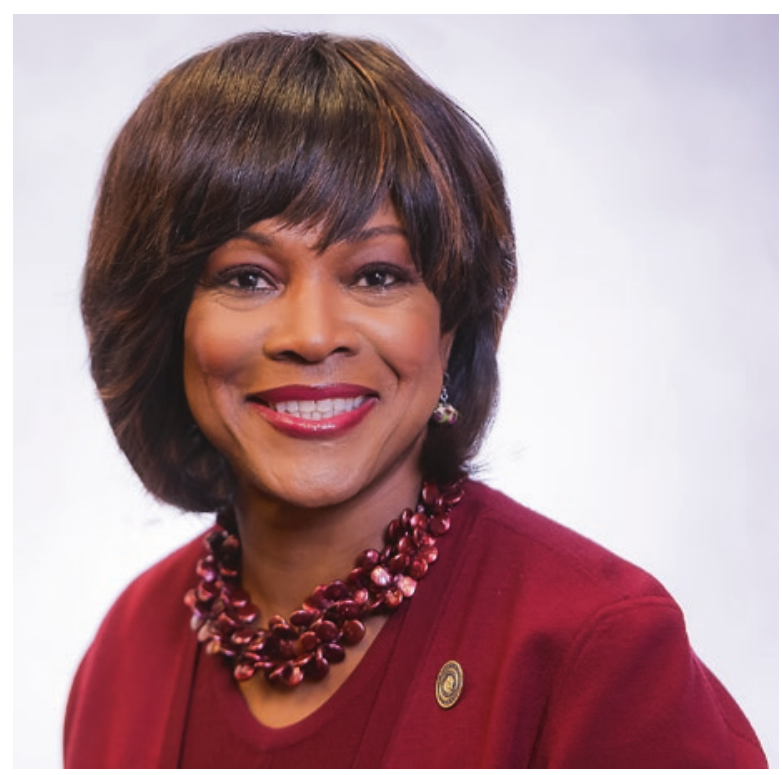

22. Wayne A.I. Frederick, MD, MBA (Fig. 6.56). Undergraduate and medical school: Bachelor of Science (BS)/MD dual degree program, Howard University. Postgraduate: Research and fellowship in surgical oncology, University of Texas MD Anderson Cancer Center. Born in Trinidad, he entered Howard at age 16 fueled by his desire to become a physician and to learn more about sickle cell anemia. A consummate teacher, researcher, and exponent of equity and of the recognition of unconscious bias in medicine. Medical research focuses on narrowing racial, ethnic, and gender disparities in cancer care outcomes, especially concerning gastrointestinal disease. He writes and lectures on the impact of HBCUs and the underrepresentation of African American men in medical school. Currently President of Howard University College of Medicine, having served previously as Provost and Chief Academic Officer.

23. Harold P. Freeman, MD (Fig. 6.57). Undergraduate: Catholic University of America, Washington, DC. Medical school: Howard University College of Medicine. Founder, President, and CEO of the Harold P. Freeman Patient Navigation Institute in New York City. Pioneered the concept of "patient navigation," to provide low-income patients with personal guides through the healthcare system. Director of Surgery at Harlem Hospital (1974-99); Professor of Clinical Surgery at Columbia University College of Physicians and Surgeons. Founder, Past President, and Chair Emeritus of the Ralph Lauren Center for Cancer Care and Prevention. Founding Director of the National Cancer Institute (NCI) Center to Reduce Cancer Health Disparities (2001-2005) while also serving as Associate Director of the NCI. Founder and Medical Director of the Breast Examination Center of Harlem (a program of Memorial Sloan Kettering Cancer Center), since 1979. Elected to the Institute of Medicine 
Fig. 6.56 Wayne

A.I. Frederick, MD,

MBA. (Photograph

courtesy of Dr. Frederick)

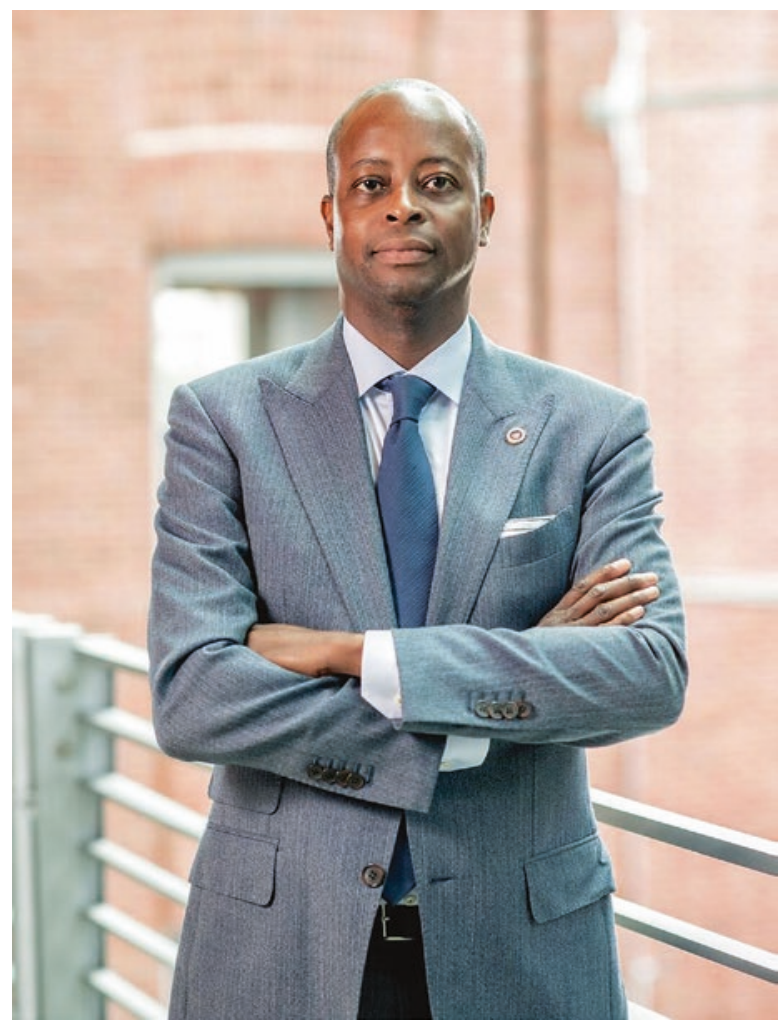

(now known as the National Academy of Medicine) in 1997. National President of the American Cancer Society (1988-1989); chief architect of the American Cancer Society initiative on Cancer in the Poor, for which the Harold P. Freeman Award was established in 1990 to honor his work in that field. Leading authority on the interrelationships between race, poverty, and cancer, awarded the 2000 Mary Woodard Lasker Public Service Award for addressing the social determinants of disease.

24. Cato T. Laurencin, MD, PhD (Fig. 6.58). Undergraduate: BSE chemical engineering, Princeton University, Princeton, NJ. Medical school: Harvard Medical School (magna cum laude). Postgraduate: PhD, Biochemical Engineering/ Biotechnology, Massachusetts Institute of Technology, Cambridge, MA. Albert and Wilda Van Dusen distinguished endowed Professor of Orthopedic Surgery, the eighth designated university professor in the university's 135-year history. Professor of Chemical, Materials, and Biomedical Engineering and CEO of the Connecticut Convergence Institute for Translation in Regenerative Engineering at the University of Connecticut, formerly serving there as Dean of the Medical School and Vice President for Health Affairs. Received NIH Director's Pioneer Award for work in regenerative engineering and the Philip Hauge Abelson Prize from the American Association for the Advancement of Science (AAAS). 
Fig. 6.57 Harold

P. Freeman

MD. (Photograph courtesy

of Dr. Freeman)

Fig. 6.58 Cato

T. Laurencin, MD,

$\mathrm{PhD}$. (Photograph courtesy

of Dr. Laurencin)
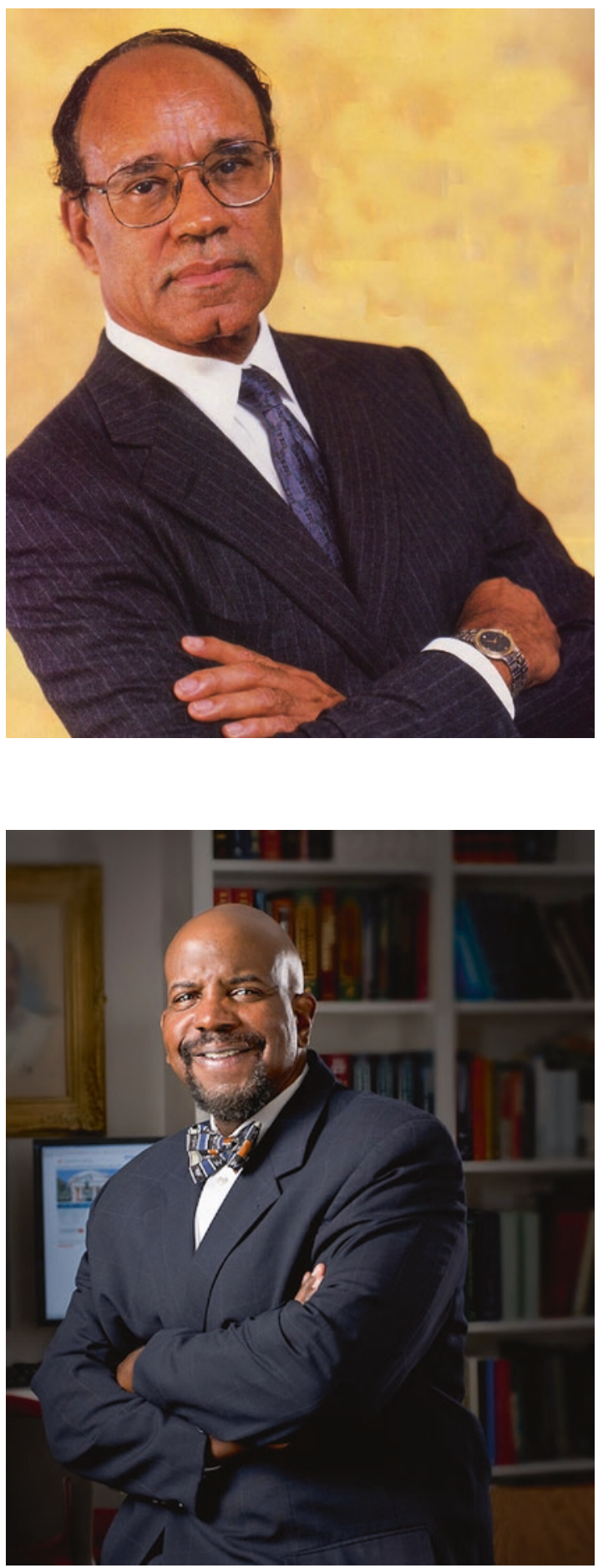
First to receive both the Walsh McDermott Medal from the National Academy of Medicine and the Simon Ramo Founder's Award from the National Academy of Engineering. The first orthopedic surgeon and first black physician to receive the National Medal of Technology and Innovation, the nation's highest honor for technological achievement, from President Barack Obama in a White House ceremony. Received the AAAS Mentor Award, the Beckman Award for Mentoring, and the Presidential Award for Excellence in Science, Math, and Engineering Mentoring. Editor in Chief, Journal of Racial and Ethnic Health Disparities. Co-founder and Founding Chair, W. Montague Cobb/NMA Health Institute, dedicated to addressing health disparities. Member of the National Academy of Medicine, National Academy of Engineering, and American Academy of Arts and Sciences; elected fellow of a number of international science academies.

25. W. Michael Byrd, MD, MPH (Fig. 6.59). Undergraduate: Morehouse College. Medical school: Meharry Medical College. Postgraduate: MPH, Harvard H. T. Chan School of Public Health, where he has taught for over 25 years as a senior research scientist in the Department of Health Policy and Management. Battalion Surgeon in the US Army Medical Corps on active duty in the Vietnam

Fig. 6.59 W. Michael Byrd, MD,

MPH. (Photograph @Don West, with permission)

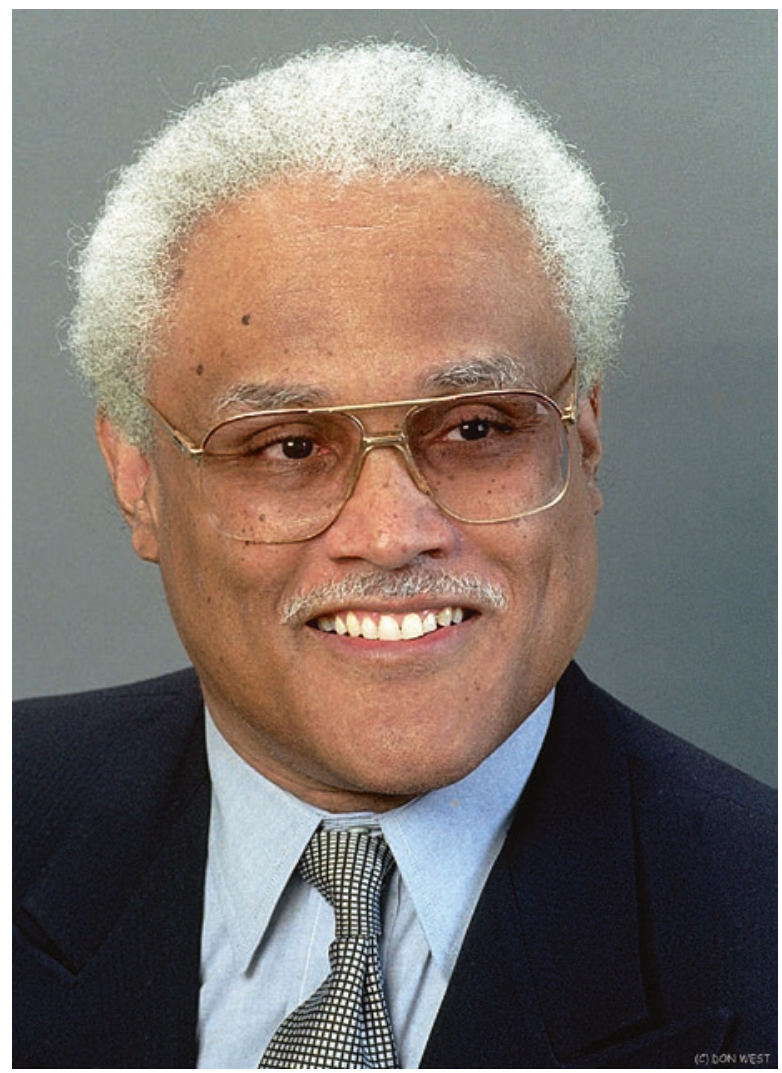


War, awarded the Bronze Star Medal. Obstetrician and gynecologist who has practiced his specialty for over four decades. A nationally and internationally recognized authority on African American and disadvantaged population health and healthcare; racial and ethnic disparities; health reform; health equity; and health policy and health service delivery, called upon as a consultant by presidential administrations, the National Academy of Medicine, the Congressional Black Caucus, the NAACP, and the NMA. Author of the book An American Health Dilemma: (Vol. 1) A Medical History of African Americans and the Problem of Race: Beginnings to 1900 and (Vol. 2) Race, Medicine, and Health Care in the United States, 1900-2000, written with his wife and colleague Dr. Linda A. Clayton. The authors are currently working on the 2 nd edition and 3rd volume.

26. Linda A. Clayton, MD, MPH (Fig. 6.60). Undergraduate: North Carolina Central University, Durham. Medical school: Duke University Medical School, Durham, NC. Postgraduate: MPH, Harvard H. T. Chan School of Public Health. Obstetrician and gynecologist and the first African American woman to be subspecialty trained in surgical gynecologic oncology. For several decades has provided direct patient care through radical pelvic surgery and other oncologic

Fig. 6.60 Linda A. Clayton, MD, MPH. (Photograph ODon West, with permission)

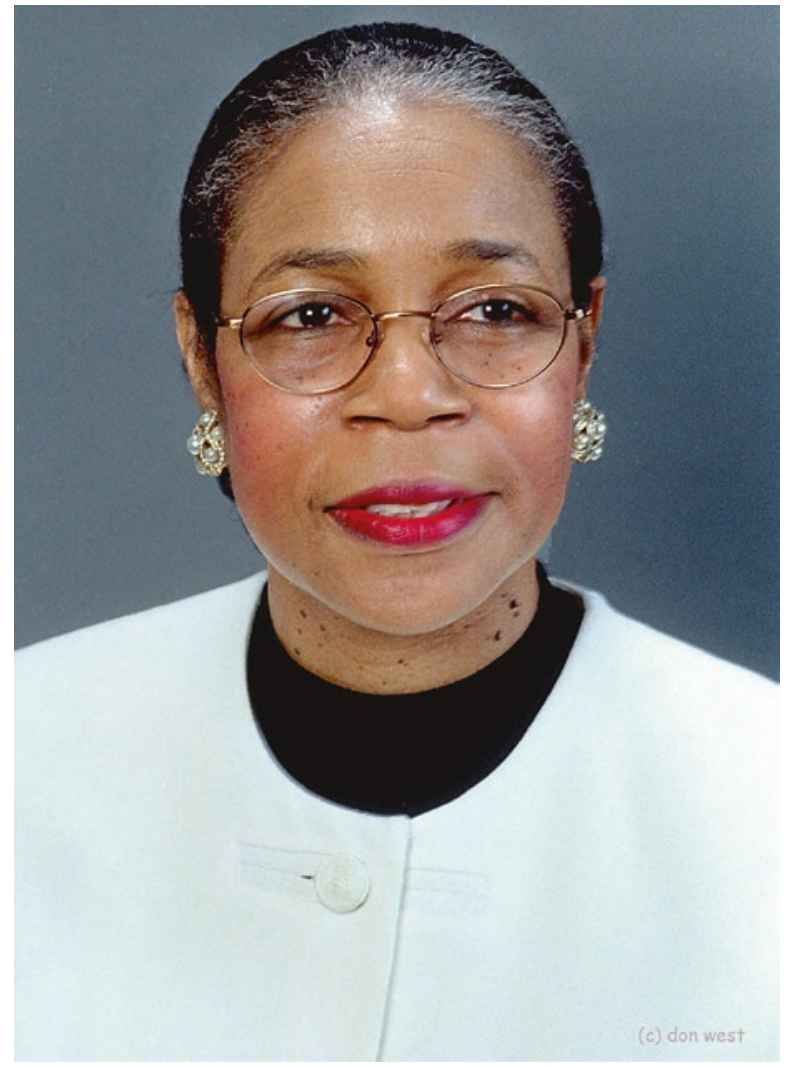


therapeutic interventions for women with pelvic malignancies. Extensive experience in enrolling patients into cancer clinical trials; has conducted biomedical research in laboratory and clinical settings since the early 1980s. Has provided expert medical and policy analysis since the 1990s. A nationally and internationally recognized authority on African American and disadvantaged population health; racial and ethnic disparities; health reform; and health equity. Called upon as a consultant by presidential administrations, the National Cancer Institute, the Congressional Black Caucus, the Office of Minority Health, and the NMA. Senior research scientist in the Department of Health Policy and Management at the Harvard H. T. Chan School of Public Health. Author of the book: An American Health Dilemma: (Vol. 1) A Medical History of African Americans and the Problem of Race: Beginnings to 1900 and (Vol. 2) Race, Medicine, and Health Care in the United States, 1900-2000, written with her husband and colleague Dr. W. Michael Byrd; the authors are currently working on the 2nd edition and 3rd volume.

27. Deborah Prothrow-Stith, MD (Fig. 6.61). Undergraduate: Spelman College, Atlanta, GA. Medical school: Harvard Medical School. Residency: Internal

Fig. 6.61 Deborah Prothrow-Stith, MD. (Photograph courtesy of Dr. Prothrow-Stith)

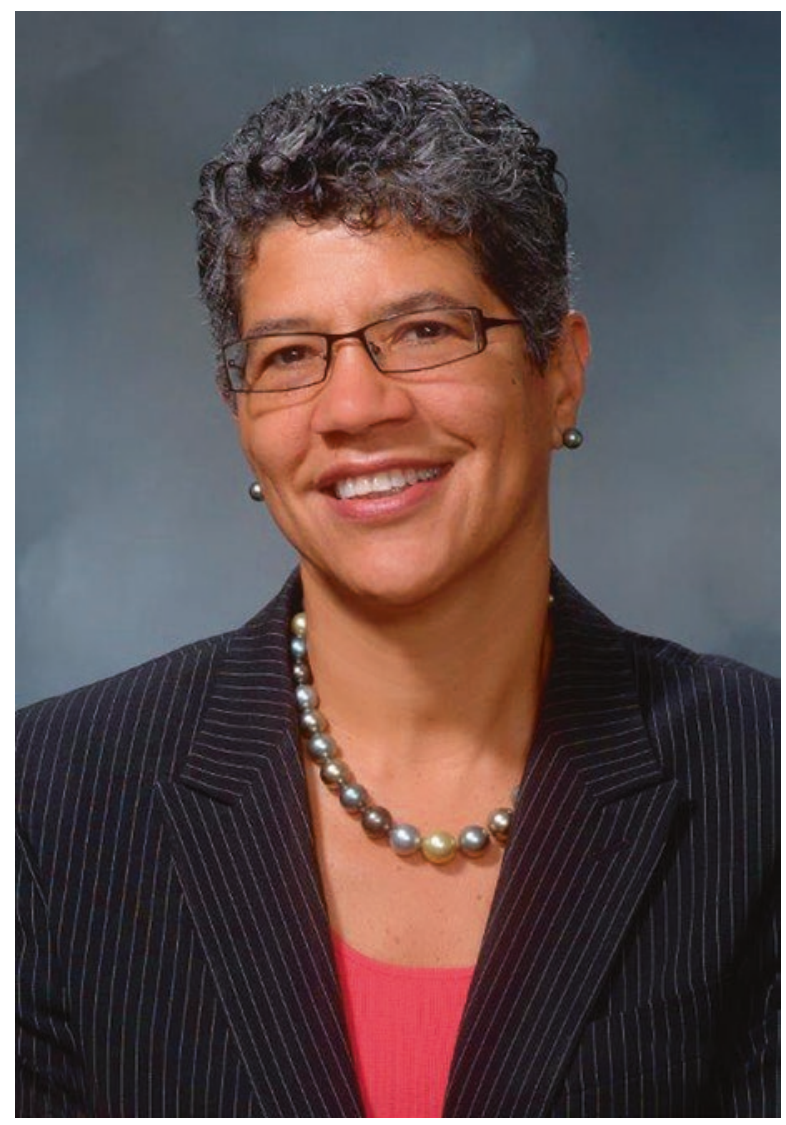


medicine, Boston City Hospital. Dean and Professor of Medicine, College of Medicine at Charles R. Drew University of Medicine and Science/ UCLA. Internationally recognized public health leader, previously served as the Henry Pickering Walcott Professor of Public Health Practice and Associate Dean for Diversity at the Harvard H. T. Chan School of Public Health. Working as a physician in inner-city Boston, broke new ground in defining youth violence as a public health problem. Author of Deadly Consequences: How Violence Is Destroying Our Teenage Population and a Plan to Begin Solving the Problem (1991), the first book to present the public health perspective on violence; co-author of Murder Is No Accident: Understanding and Preventing Youth Violence in America (2004). Appointed the first woman Commissioner of Public Health for Massachusetts by Governor Michael Dukakis. Established the nation's first Office of Violence Prevention in a state department of public health, expanded prevention programs for HIV/AIDS, and increased drug treatment and rehabilitation programs. Lived in Tanzania during her husband's tenure as US Ambassador, working with Muhimbili National Hospital and an NGO that runs the first HIV clinic in Tanzania. Member of the National Academy of Medicine. Recipient of the 1993 World Health Day Award, the 1989 Secretary of Health and Human Service Award, and a Presidential appointment to the National Commission on Crime Control and Prevention.

28. Julian Haywood, MD (Fig. 6.62) Undergraduate: Hampton Institute (high honors). Medical school: Howard University, with honors. Residency: Internal Medicine, LA County General Hospital. Cardiology fellowship: White Memorial Hospital, Los Angeles. Traveling fellowship under Oxford University Regius Professor of Medicine George Pickering. Joined faculty University of Southern California in 1963. Retired in 2019 as Professor Emeritus in Medicine, USC, and Honored Clinical Professor of Medicine, Loma Linda University School of Medicine. Extensive publication in hypertension, population research, clinical cardiology and arrhythmias, heart disease in sickle cell anemia patients, and biomedical engineering. Established the coronary care unit at LA County General Hospital, one of the first in the world (1966), which was renamed for him in 2016; developed the first digital heart rhythm monitor (1969); established the Comprehensive Sickle Cell Center at LA County General Hospital, one of the first in the nation (1972); a Founding Member of ABC (1974). Member of the Alpha Omega Alpha Honor Medical Society and a Distinguished Alumnus of Hampton and Howard Universities.

Alvin F. Poussaint, MD (Fig. 6.63). Undergraduate: Columbia University. Medical school: Cornell University. Postgraduate training: UCLA Neuropsychiatric Institute, serving as Chief Resident in Psychiatry; MS, Psychopharmacology. Southern Field Director of the Medical Committee for Human Rights in Jackson, Mississippi (1965-1967), providing medical care to civil rights workers and aiding desegregation of hospitals and health facilities throughout the South. Medical foot soldier for the march from Selma to Montgomery, Alabama, in March 1965 with Rev. Dr. Martin Luther King, Jr. Joined Tufts Medical School faculty as director of a psychiatry program in a 
Fig. 6.62 L. Julian

Haywood,

MD. (Photograph courtesy

of Dr. Haywood)

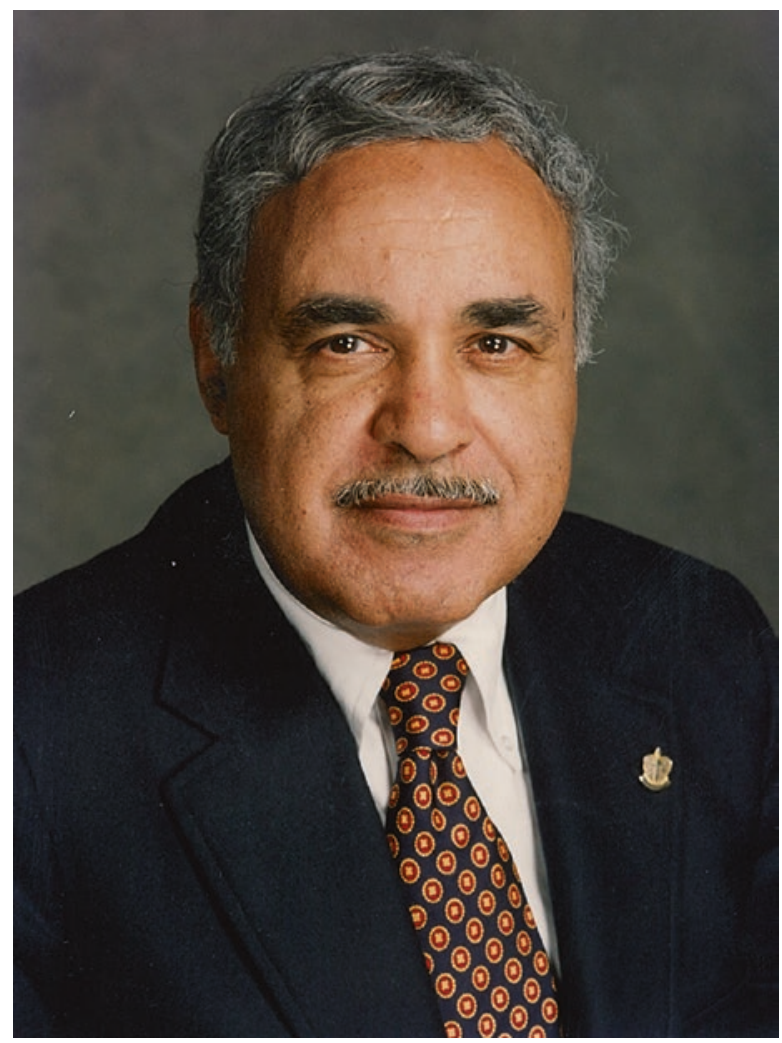

low-income housing development before joining Harvard Medical School faculty in 1969, serving as Dean of Students and Director of the Office of Recruitment and Multicultural Affairs. Instrumental in expanding the enrollment of underrepresented medical students and mentoring their academic careers. Also served on the staff of Harvard's Judge Baker's Children's Center. Currently Professor of Psychiatry, Emeritus, Harvard Medical School. Author of Why Blacks Kill Blacks (1972); co-author of Raising Black Children (1992); and co-author of Lay My Burden Down (2000). Awarded the Herbert W. Nickens Award, recognizing outstanding contributions promoting justice in medical education and healthcare by the Association of American Medical Colleges in 2010. Distinguished life fellow of the American Psychiatric Association, a fellow of the AAAS, a life member of the American Academy of Child and Adolescent Psychiatry, and a member of the American Academy of Arts and Sciences. Recipient of the NMA Distinguished Service Award.

29. Risa Lavizzo-Mourey, MD, MBA (Fig. 6.64) Medical school: Harvard Medical School. Internship and residency: Internal Medicine, Brigham and Women's Hospital, Boston, MA. Postgraduate: MBA, Wharton School of the University of Pennsylvania. President Emerita and former CEO, Robert Wood Johnson 
Fig. 6.63 Alvin

F. Poussaint,

MD. (Photograph courtesy

of Dr. Poussaint)

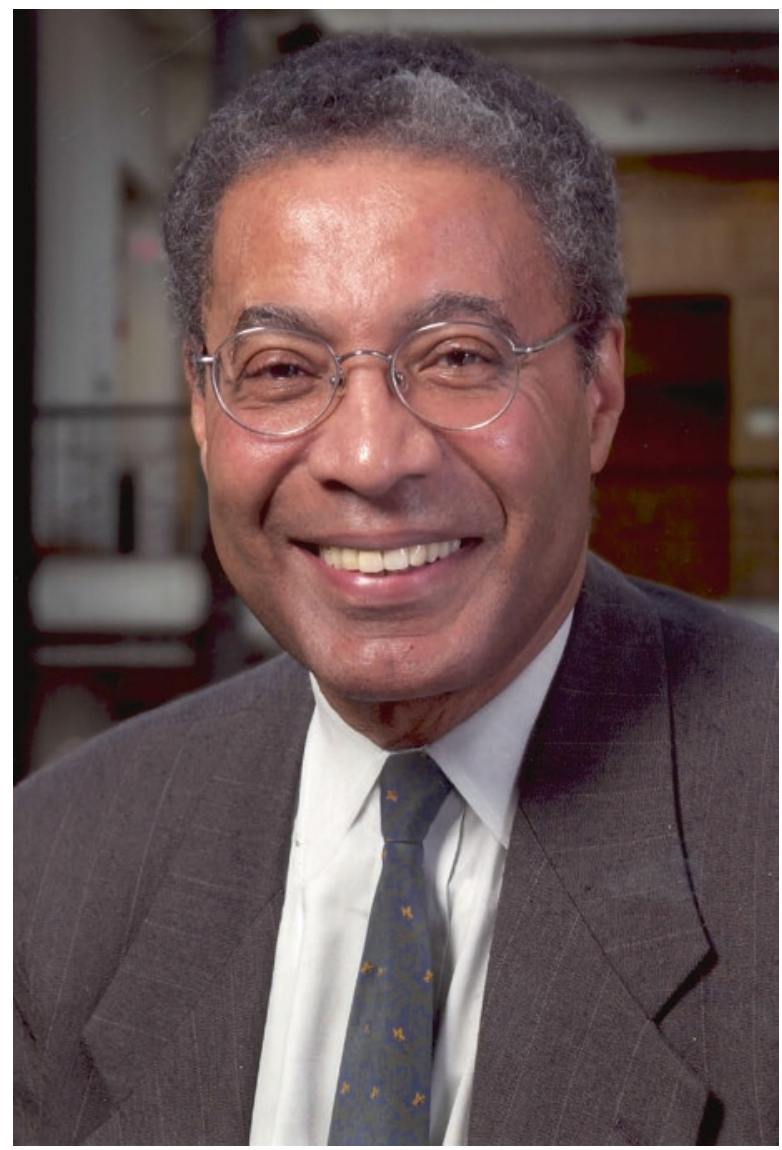

Foundation (RWJF) (2003-2017), where she administered an endowment of $\$ 10.5$ billion dollars, the nation's largest charitable fund devoted entirely to health. Spearheaded bold health initiatives during her tenure such as creating healthier, more equitable communities; strengthening the integration of health systems and services; and ensuring every child in the United States has the opportunity to grow up at a healthy weight. This work culminated in the Foundation's vision of building a culture of health, enabling everyone in America to live longer, healthier lives. Served as deputy administrator for what is now the Agency for Healthcare Research and Quality (AHRQ) and has worked on the White House Health Care Reform Task Force. Served on numerous federal advisory committees and was appointed by President Barack Obama to the President's Council on Fitness, Sports, and Nutrition. Currently serves as the 19th Penn Integrates Knowledge University Professor at the University of Pennsylvania, with joint faculty appointments at the Perelman School of Medicine, the School of Nursing, and the Wharton School. Recipient of the Distinguished Service Award from the NMA. 
Fig. 6.64 Risa LavizzoMourey, MD. (Photograph courtesy of Dr.

Lavizzo-Mourey)

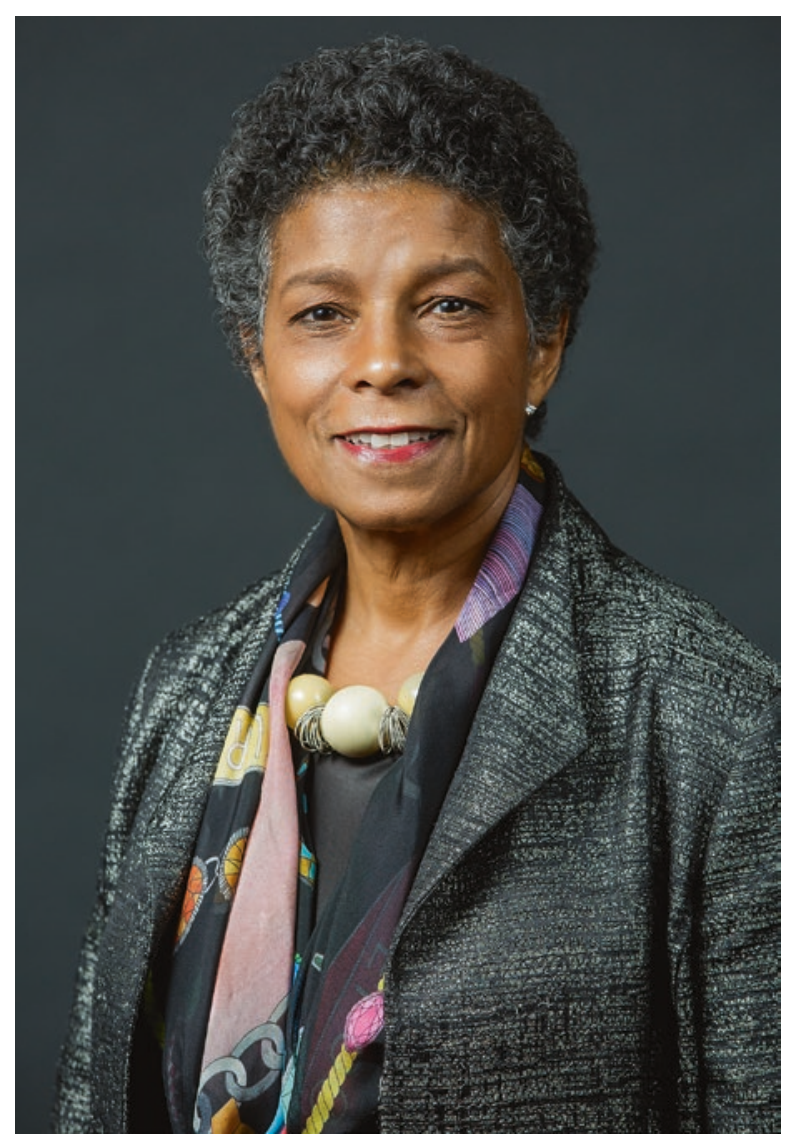

30. Robert K. Ross, MD, MPA (Fig. 6.65). Undergraduate, medical school, postgraduate (Master of Public Administration): University of Pennsylvania. Currently, President and CEO of The California Endowment, a private, statewide health foundation established in 1996 to address the health needs of Californians. Prior to his appointment in September 2000, served as director of the Health and Human Services Agency for the County of San Diego from 1993 to 2000. Extensive background in health philanthropy as a public health administrator and as a clinician. Commissioner, Philadelphia Department of Public Health; medical director for LINK School-Based Clinic Program, Camden NJ; instructor of clinical medicine, Children's Hospital of Philadelphia; and faculty member at San Diego State University's School of Public Health. Member of the President's Advisory Commission on Educational Excellence for African Americans; Co-chair, Diversity in Philanthropy Coalition; member of the California Health Benefit Exchange Board, the Rockefeller Philanthropy Advisors Board, National Vaccine Advisory Committee, and on the boards of Grantmakers in Health, the National Marrow Donor Program, San Diego United Way, and the Jackie Robinson YMCA. Served on the President's Summit 
Fig. 6.65 Robert K. Ross, MD. (Photograph courtesy of Dr. Ross)

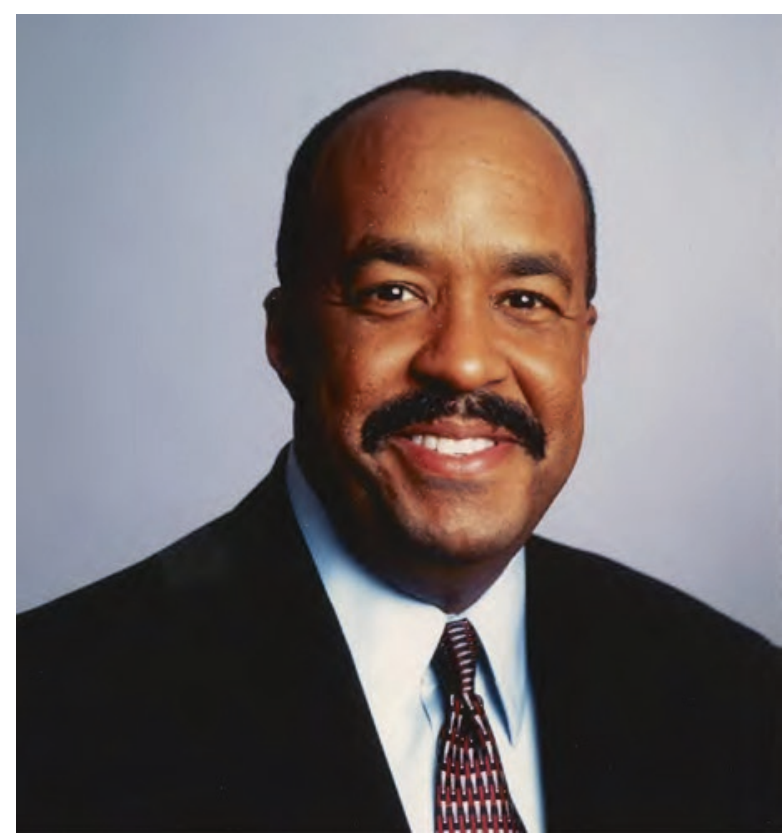

for America's Future and as chair of the national Boost for Kids Initiative. Named by the Council on Foundations as the Distinguished Grantmaker of the Year for 2008.

31. Gary H. Gibbons, MD (Fig. 6.66) Undergraduate: Princeton University. Medical school: Harvard, magna cum laude. Residency and Cardiology fellowship: Brigham and Women's Hospital and Harvard Medical School. Appointed Director of the National Heart, Lung, and Blood Institute (NHLBI) of the NIH in 2012. Oversees an annual budget of \$3 billion and supervises 917 employees. Former faculty member at Stanford University and Harvard Medical School. Prior to his appointment to NHLBI, he established the Cardiovascular Research Institute at Morehouse School of Medicine, which developed into a center of excellence focusing on discoveries related to the cardiovascular health of minorities. He was also Chair of the Physiology Department and Professor of Medicine and Physiology. Elected to the Institute of Medicine (now known as the National Academy of Medicine, one of three academies that make up the US National Academies of Sciences, Engineering, and Medicine) and was a Robert Wood Johnson Foundation Minority Faculty Development Awardee.

32. Paula A. Johnson, MD, MPH (Fig. 6.67) Undergraduate: Harvard and Radcliffe. Medical school and MPH: Harvard Medical School. Residency in Internal Medicine and Cardiology Fellowship: Brigham and Women's Hospital and Harvard Medical School, where she was the first African American chief resident in medicine. Specialty: Cardiology. 14th President of Wellesley College. The first African American to lead that institution. Founder and former Executive Director of the Connors Center for Women's Health and Gender 
Fig. 6.66 Gary

H. Gibbons,

MD. (Photograph courtesy of the National Institutes of Health)

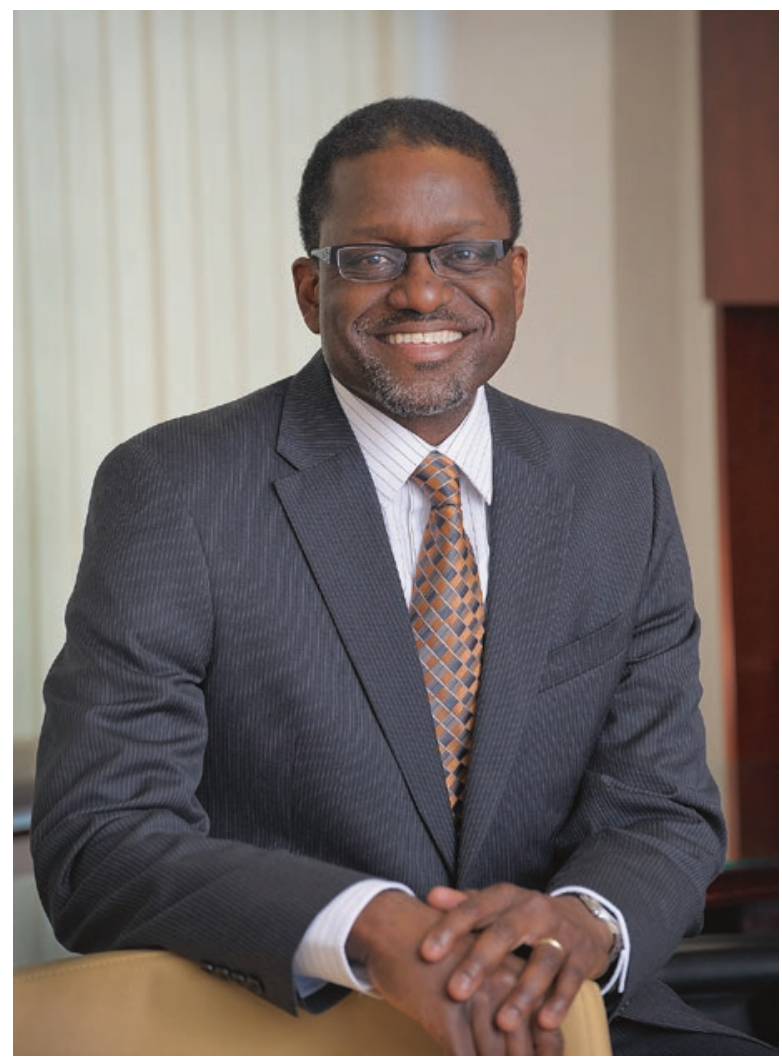

Biology and former Chief, Division of Women's Health, both at Brigham and Women's Hospital, leading research into furthering our knowledge of biological differences between males and females that also resulted in advances in health policy. Former Grayce A. Young Family Professor of Medicine in Women's Health at Harvard Medical School, a professorship named in honor of her mother, and professor of Epidemiology at the Harvard T. H. Chan School of Public Health. The first African American to achieve the rank of professor at Brigham and Women's Hospital. A member of the AAAS and of the National Academy of Medicine. As president of Wellesley, she has advanced women's higher education, championing cross-campus efforts to integrate the ideals of inclusive excellence into the academic program and residential life. With a belief that health and wellness are crucial to fulfilling one's potential, she is reimagining how a college integrates a public health agenda as an essential component of a college education. The College is developing new opportunities by drawing on the synergies found at the intersection of science, the humanities, and social sciences. 
Fig. 6.67 Paula

A. Johnson,

MD. (Photograph courtesy

of Dr. Johnson)

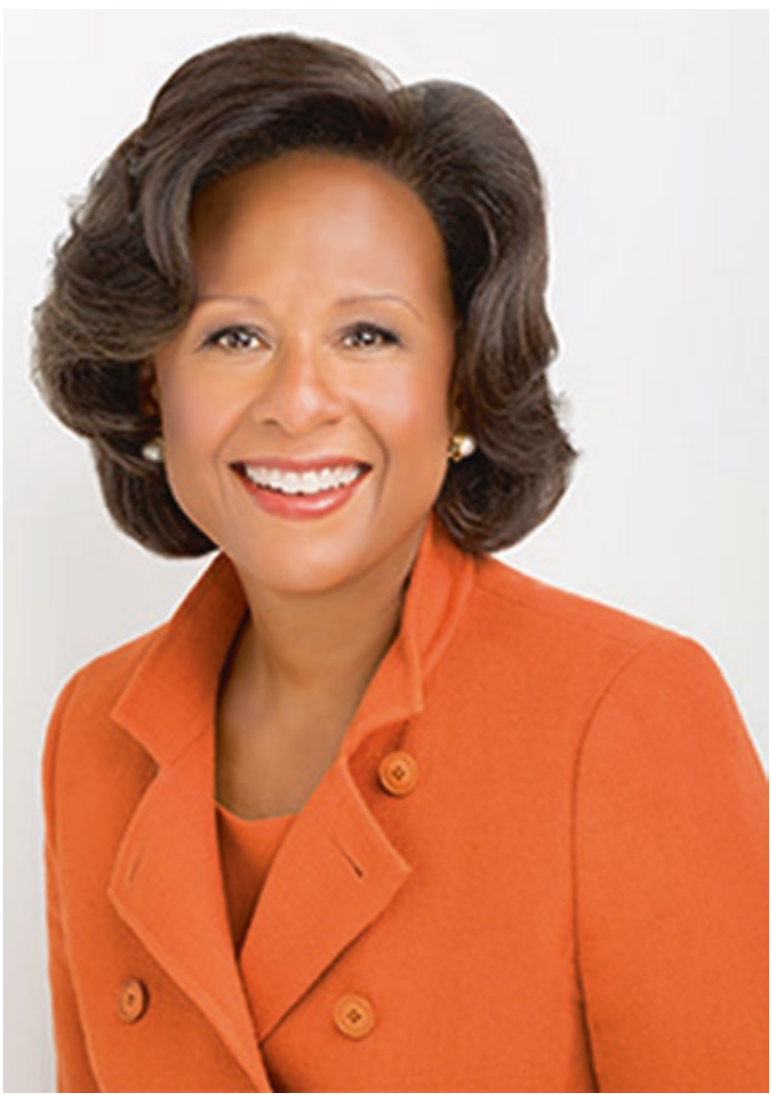

In conclusion, I have made an attempt in this chapter to recognize and give credit to some of the black medical heroes in our country's history. Others are included in other chapters in this book, but I acknowledge that there are still several individuals who are not accounted for. With all respect that is due to them, I give a silent, unwritten tribute to all of them as well as to all who appear on these pages.

\section{References}

1. Wynn LT. Robert Fulton Boyd (1855-1912). In: Lovett BL, Wynn LT, editors. AfricanAmerican members of the Tennessee General Assembly, 1873-1995. http://ww2.tnstate.edu/ library/digital/RFBoyd.htm.

2. Dr. Charles Victor Roman. J Natl Med Assoc. 1953;45(4):301-5.

3. Morrison SM, Fee E, Charles V. Roman: physician, writer, educator, historian (1864-1934). Am J Public Health. 2010;100(Suppl 1):S69.

4. Dr. Nathan F. Mossell. Oldest Active Negro Physician, Uncle to Paul Robeson, Was 90. The New York Times. 29 Oct 1946, p. 23. 
5. Penn University Archives \& Records Center. Penn People. Nathan Francis Mossell. 1856-1946. https://archives.upenn.edu/exhibits/penn-people/biography/nathan-francis-mossell. Accessed 24 Dec 2019.

6. Epps CH, Johson DG. Vaughan Al. Black medical pioneers. African-American 'firsts' in academic and organized medicine. Part three. J Natl Med Assoc. 1993;85(10):777-96.

7. The National Library of Medicine. National Institutes of Health, Health \& Human Services, Changing the Face of Medicine. Dr. M. Jocelyn Elders. https://cfmedicine.nlm.nih.gov/physicians/biography_98.html. Accessed 23 Dec 2019.

8. U.S. Department of Health \& Human Services. Surgeon General.gov. Previous Surgeons General. David Satcher (1998-2002) http://wayback.archive-it.org/3929/20171201191751/ https://www.surgeongeneral.gov/about/previous/biosatcher.html. Accessed 24 Dec 2019.

9. The National Library of Medicine. National Institutes of Health, Health \& Human Services, Changing the Face of Medicine. Dr. Regina Marcia Benjamin. https://cfmedicine.nlm.nih.gov/ physicians/biography_31.html. Accessed 24 Dec 2019.

10. American Society of Anesthesiologists Congratulates Jerome Adams, M.D., for Surgeon General Nomination. American Society of Anesthesiologists. 29 Jun 2017. https://www.asahq. org/about-asa/newsroom/news-releases/2017/06/surgeon-general-nomination. Accessed 24 Dec 2019.

11. U.S. National Library of Medicine. Opening Doors: Contemporary African American Academic Surgeons. It's attitude, not aptitude, that determines altitude (Claude H. Organ). https://www.nlm.nih.gov/exhibition/aframsurgeons/organ.html. 14 Nov 2006; last reviewed: 19 Aug 2011; last updated 17 Jul 2013. Accessed 24 Dec 2019. 